Crustal Evolution along the Early Ordovician Proto-Andean Margin of Gondwana: Trace Element and Isotope Evidence from the Complejo Igneo Pocitos (Northwest Argentina) Author(s): Thorsten Kleine, Klaus Mezger, Udo Zimmermann, Carsten Münker and Heinrich Bahlburg

Source: The Journal of Geology, Vol. 112, No. 5 (September 2004), pp. 503-520

Published by: The University of Chicago Press

Stable URL: http://www.jstor.org/stable/10.1086/422663

Accessed: 20-09-2016 06:40 UTC

JSTOR is a not-for-profit service that helps scholars, researchers, and students discover, use, and build upon a wide range of content in a trusted digital archive. We use information technology and tools to increase productivity and facilitate new forms of scholarship. For more information about JSTOR, please contact support@jstor.org.

Your use of the JSTOR archive indicates your acceptance of the Terms \& Conditions of Use, available at http://about.jstor.org/terms

The University of Chicago Press is collaborating with JSTOR to digitize, preserve and extend access to The Journal of Geology 


\title{
ARTICLES
}

\section{Crustal Evolution along the Early Ordovician Proto-Andean Margin of Gondwana: Trace Element and Isotope Evidence from the Complejo Igneo Pocitos (Northwest Argentina)}

\author{
Thorsten Kleine, ${ }^{1}$ Klaus Mezger, Udo Zimmermann, ${ }^{2}$ \\ Carsten Münker, and Heinrich Bahlburg ${ }^{3}$ \\ Zentrallabor für Geochronologie, Institut für Mineralogie, Universität Münster, \\ Corrensstrasse 24, 48149 Münster, Germany \\ (e-mail: kleine@erdw.ethz.ch)
}

\begin{abstract}
A B S T R A C T
The Paleozoic geodynamic evolution of the proto-Andean margin of Gondwana was characterized by extensive subduction processes associated with the docking of several terranes. The major and trace element as well as $\mathrm{Sr}-\mathrm{Nd}-\mathrm{Pb}$ isotope composition of plutonic rocks from the Complejo Igneo Pocitos (CIP) are used here to constrain the processes of magma genesis in the Early Ordovician continental arc along the proto-Andean margin of Gondwana in northern Chile and northwestern Argentina. U-Pb sphene ages of $476 \pm 2 \mathrm{Ma}$ for the CIP date the time of intrusion. The CIP comprises two magmatic suites, each with a distinct and homogeneous isotope composition that was acquired by magmatic processes in the deep crust or mantle. Both suites are strongly enriched in incompatible trace elements and display a Sr-Nd isotope composition intermediate between mid-ocean ridge basalt (MORB) and Andean continental crust. The petrological, geochemical, and isotopic characteristics are best modeled by generation of the CIP melts in a subduction setting. Multicomponent modeling shows that the trace element and isotope inventory of group 1 samples can be generated by admixture of $\sim 0.5 \%$ melts from subducted sediments and $1 \%-2 \%$ of MORB-derived fluids to the mantle source. Constant initial $\mathrm{Sr}$ and $\mathrm{Nd}$ isotope compositions at varying $\mathrm{SiO}_{2}$ contents for both suites exclude significant modification of the melts by assimilation and fractional crystallization processes in upper-crustal levels. Assimilation of group 1 parental magmas in the deep crustal MASH (melting, assimilation, storage, and homogenization) zone with $20 \%-25 \%$ crustal material, however, produced the group 2 parental magmas. The CIP can be considered to be the northern continuation of the Early Ordovician Famatinian arc known from central Argentina. As indicated by the $\mathrm{Nd}-\mathrm{Pb}$ isotope composition of the CIP, this arc was built on continental crust of Middle Proterozoic age. Similar protolith ages have been reported for the Famatinian arc in the southern Andes and for the Late Precambrian-Early Paleozoic metamorphic basement of the central Andes. The identification of MASH processes requires a thick continental crust in order to enable melting and assimilation at the base of the crust. Thickening of the crust can be related to the Pampean orogeny at 500 Ma. Magmatic rocks from the Famatinian arc in the southern Andes display a more crustlike Sr-Nd isotope signature compared with the CIP, suggesting that crustal thicknesses in the Early Ordovician continental arc decreased from south to north.
\end{abstract}

\section{Introduction}

Active continental margins are a major site of continental crust formation and orogenic activity. The

Manuscript received October 7, 2003; accepted February 24, 2004.

${ }^{1}$ Present address: Institut für Isotopengeologie und Mineralische Rohstoffe, Sonneggstrasse 5, CH-8092 Zürich, Switzerland.

${ }^{2}$ Department of Geology, Rands Afrikaans University, P.O. Box 524, 2006 Auckland Park, Johannesburg, South Africa.

${ }^{3}$ Geologisch-Paläontologisches Institut, Universität Münster, Corrensstrasse 24, 48149 Münster, Germany. chemical and isotopic composition of magmas generated in continental arc settings reflects contributions of several sources including the mantle wedge beneath the arc, fluids derived from the midocean range basalt (MORB) portion of the downgoing slab, melts from subducted sediments, and assimilated continental crust (e.g., Arculus and Powell 1986; Ellam and Hawkesworth 1988; Hildreth and Moorbath 1988; Pearce and Peate 1995; Johnson and Plank 1999). Crustal contributions to 


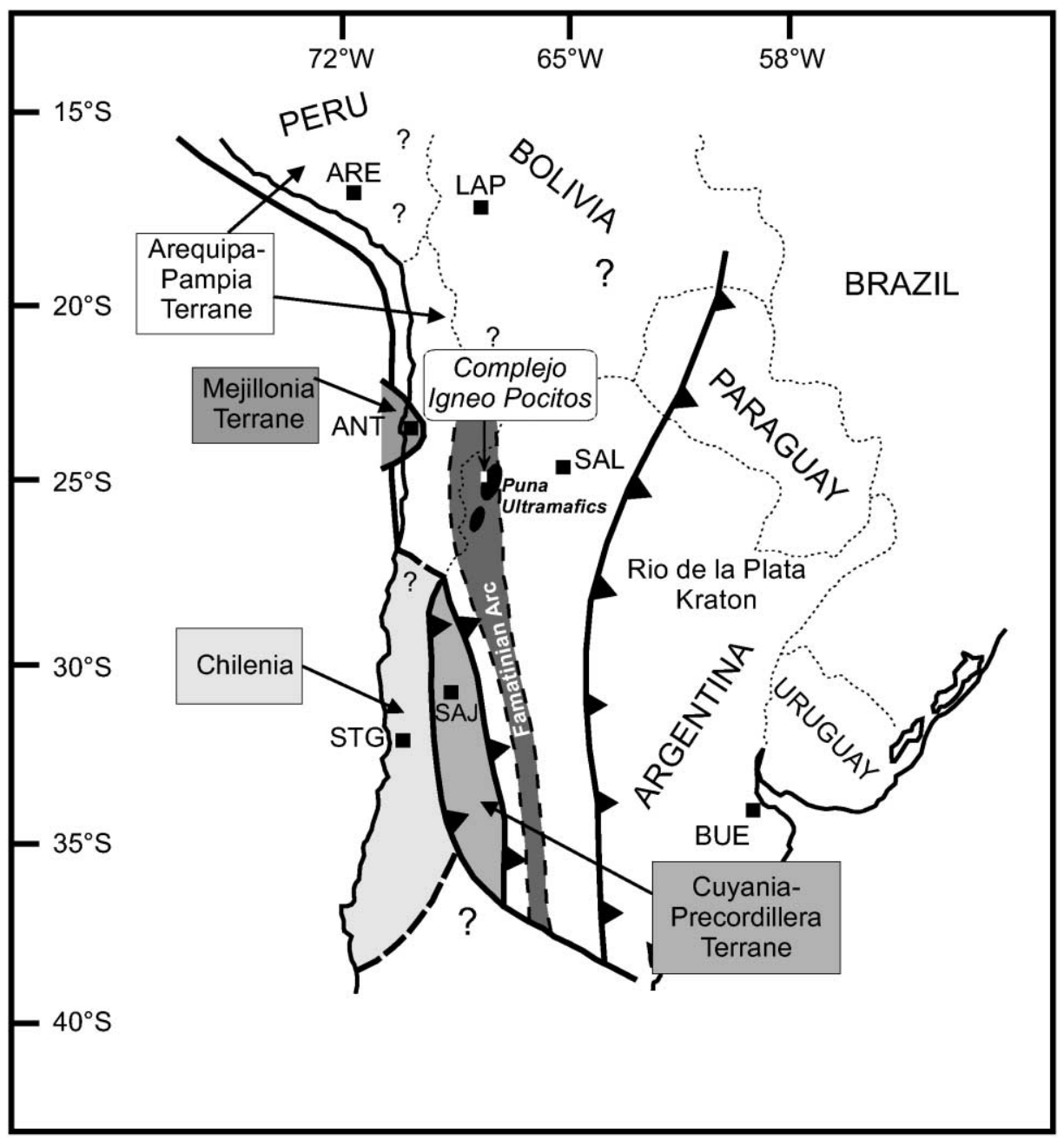

Figure 1. Terrane map for northwestern Argentina and northern Chile with the location of the Complejo Igneo Pocitos (modified from Bahlburg et al. 2000).

primary mantle-derived magmas may occur by combined assimilation and fractional crystallization (AFC) in shallow crustal levels (DePaolo 1981) or by melting, assimilation, storage, and homogenization (MASH) in deep crustal zones (Hildreth and Moorbath 1988; Davidson et al. 1990; McMillan et al. 1993). In the present-day volcanic zone of the Andes, which comprise one of the most prominent and best-developed examples of continental arc magmatism, variations in the chemical and isotopic composition of volcanic rocks can be related to changes in the composition and thickness of the continental crust through which the magmas pass during their ascent (e.g., Hickey et al. 1986; Hildreth and Moorbath 1988; Davidson et al. 1990; McMillan et al. 1993). In this article, crustal contributions to arc magmas in an Early Ordovician continental arc along the proto-Andean margin of
Gondwana are examined and compared to the processes active in the recent volcanic zone of the Andes. Identification and quantification of the crustal contamination processes provide constraints on the nature and structure of the continental crust onto which the Ordovician arc was built and have important implications for the understanding of the Early Paleozoic geodynamic evolution of the protoAndean margin of Gondwana.

In this article, plutonic rocks of the Complejo Igneo Pocitos (CIP) exposed in the southern Puna of northwestern Argentina (Zappettini et al. 1994) were analyzed for their major and trace element and $\mathrm{Sr}-\mathrm{Nd}-\mathrm{Pb}$ isotope composition. In addition, high precision $\mathrm{U}-\mathrm{Pb}$ ages were obtained for magmatic sphenes. The CIP was chosen for this study because the plutonic rocks presumably originated in an Ordovician continental arc along the proto-Andean 


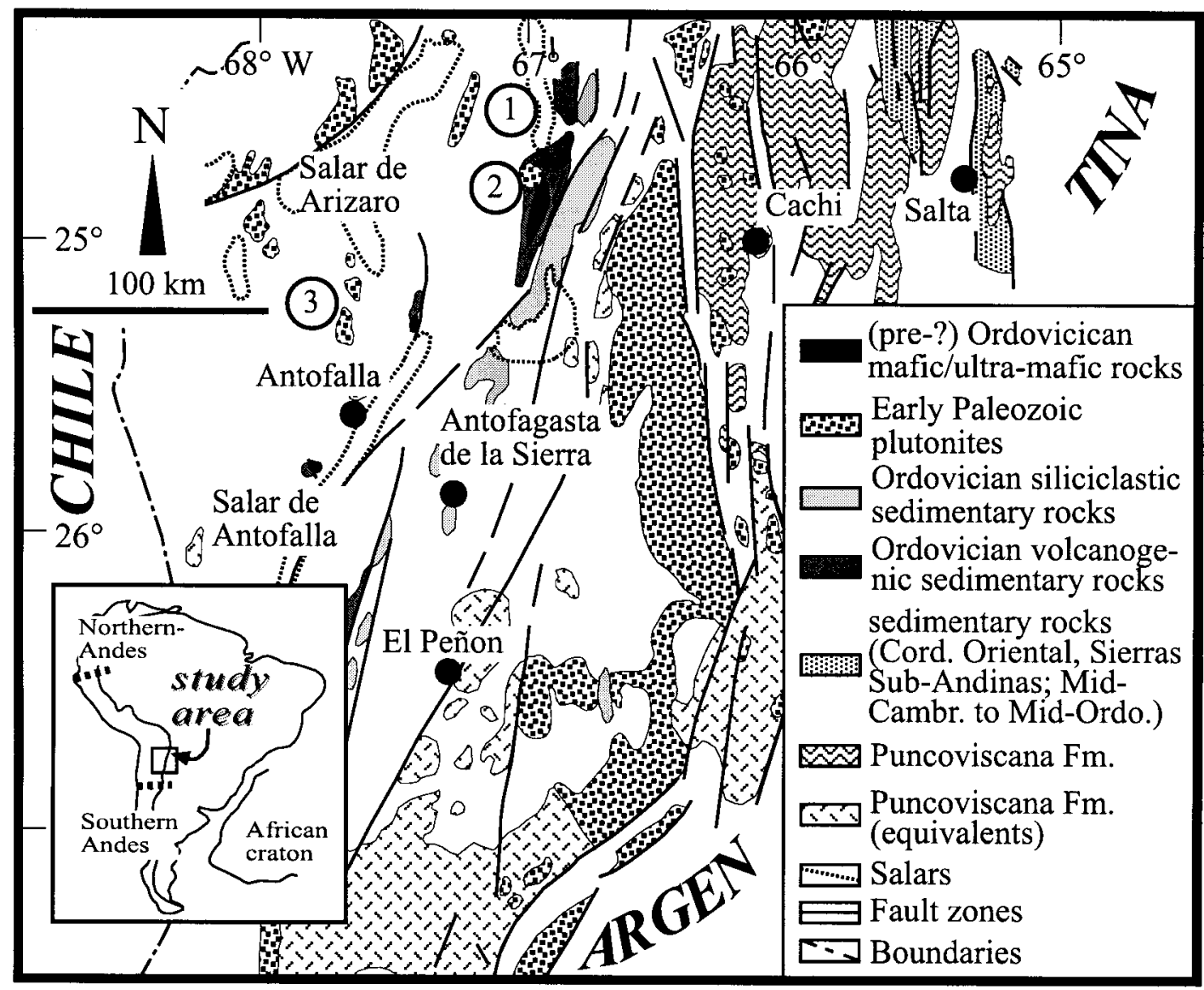

Figure 2. Geological map of the Puna region. $1=$ Salar de Pocitos; $2=$ Complejo Igneo Pocitos; $3=$ Archibarca granite (modified from Zimmermann and Bahlburg 2004).

margin of Gondwana (fig. 1; Bock et al. 2000; Zimmermann and Bahlburg 2004), and they play a key role in the reconstruction of this ancient arc system in the area of northern Chile and northwestern Argentina. In particular, the extent and significance of the arc activity in this area and further north is under debate (e.g., Bahlburg and Hervé 1997; Bock et al. 2000; Zimmermann and Bahlburg 2004). A related question is whether or not the Famatinian arc known from central Argentina (e.g., Pankhurst and Rapela 1998; Rapela et al. 1998) and the northward-lying Puna arc formed as part of the same arc system in Early Ordovician time. The major and trace element as well as $\mathrm{Sr}-\mathrm{Nd}-\mathrm{Pb}$ isotope compositions of the CIP are used here to constrain the petrogenesis of the plutonic rocks by multicomponent modeling and to put further constraints on the Early Paleozoic geodynamic evolution of the proto-Andean margin of Gondwana.

\section{Paleotectonic and Geological Setting}

The geodynamic evolution of the proto-Andean margin of Gondwana in Paleozoic times was characterized by the repeated onset of subduction processes associated with the docking of several terranes (Ramos et al. 1986; Ramos 1988; Pankhurst and Rapela 1998; Rapela et al. 1998). In the area of present-day central Chile and central Argentina, the Cuyania-Precordillera and Chilenia terranes are considered to have been amalgamated to Gondwana during the Paleozoic (fig. 1; Ramos et al. 1986; Ramos 1988). Rocks associated with Early Paleozoic subduction activity are widely distributed in the Sierras Famatina and Sierras Pampeanas in central Argentina and are generally referred to as the Famatinian arc (e.g., Pankhurst and Rapela 1998; Rapela et al. 1998). In contrast, the Paleozoic geodynamic evolution further north, in the area of 
Table 1. U-Pb Sphene Data

\begin{tabular}{|c|c|c|c|c|c|c|c|c|c|c|}
\hline \multirow[b]{2}{*}{ Sample } & \multirow[b]{2}{*}{$\begin{array}{c}\mathrm{U} \\
(\mathrm{ppm})\end{array}$} & \multirow[b]{2}{*}{$\begin{array}{c}\mathrm{Pb} \\
(\mathrm{ppm})\end{array}$} & \multicolumn{5}{|c|}{ Atomic ratios ${ }^{a}$} & \multicolumn{3}{|c|}{ Ages $(\mathrm{Ma})^{\mathrm{b}}$} \\
\hline & & & $\frac{{ }^{206} \mathrm{~Pb}}{{ }^{204} \mathrm{~Pb}}$ & $\frac{{ }^{208} \mathrm{~Pb}}{{ }^{206} \mathrm{~Pb}}$ & $\frac{{ }^{207} \mathrm{~Pb}}{{ }^{206} \mathrm{~Pb}}$ & $\frac{{ }^{207} \mathrm{~Pb}}{{ }^{235} \mathrm{U}}$ & $\frac{{ }^{206} \mathrm{~Pb}}{{ }^{238} \mathrm{U}}$ & $\frac{{ }^{206} \mathrm{~Pb}}{{ }^{238} \mathrm{U}}$ & $\frac{{ }^{207} \mathrm{~Pb}}{{ }^{235} \mathrm{U}}$ & $\frac{{ }^{207} \mathrm{~Pb}}{{ }^{206} \mathrm{~Pb}}$ \\
\hline A-G-2 & 302. & 41.43 & 0.0 & .6700 & $.05644 \pm 1$ & $.5975 \pm 3$ & $.07678 \pm$ & 477 & 476 & $470 \pm 6$ \\
\hline A-G-5 & 185.7 & - & 57.1 & .9813 & $.05640 \pm 20$ & $.5941 \pm 32$ & $.07640 \pm$ & 475 & 473 & $468 \pm 8$ \\
\hline A-5-3 & 210.6 & 32.89 & 240.4 & .9771 & $.05644 \pm 18$ & $.5963 \pm 30$ & $.07663 \pm 29$ & 476 & 475 & $470 \pm 7$ \\
\hline Т 27 & 327.7 & 47.49 & 160.5 & 6132 & $.05650 \pm 28$ & $.5994 \pm 39$ & $.07694 \pm 30$ & 478 & 477 & $472 \pm 11$ \\
\hline Т 28 & 286.6 & 39.17 & 175.4 & .6125 & $.05659 \pm 27$ & $.5789 \pm 50$ & $.07419 \pm 53$ & 461 & 464 & $476 \pm 10$ \\
\hline Т 29 & 184.1 & 39.52 & 132.1 & 1.563 & $.05637 \pm 36$ & $.5919 \pm 46$ & $.07615 \pm 29$ & 473 & 472 & $467 \pm 14$ \\
\hline
\end{tabular}

${ }^{a} \mathrm{The}{ }^{206} \mathrm{~Pb} /{ }^{204} \mathrm{~Pb}$ ratios are measured ratios. ${ }^{207} \mathrm{~Pb} /{ }^{206} \mathrm{~Pb}$ and ${ }^{208} \mathrm{~Pb} /{ }^{206} \mathrm{~Pb}$ are corrected for mass discrimination, spike, blank, and initial lead. Initial $\mathrm{Pb}$ compositions were obtained from analysis of coexisting K-feldspars.

${ }^{\mathrm{b}}$ Decay constants used in age calculations: $\lambda^{238} \mathrm{U}=1.55125 \times 10^{-10} \mathrm{yr}^{-1}, \lambda^{235} \mathrm{U}=9.8485 \times 10^{-10} \mathrm{yr}^{-1}$.

northern Chile and northwestern Argentina (southern central Andes), is much less well constrained. Major differences exist between models that propose extensive subduction processes in Ordovician times, culminating in either the docking of terranes (e.g., Ramos 1988; Bahlburg and Hervé 1997; Coira et al. 1999) or a continent-continent collision between Gondwana and Laurentia (Dalla Salda et al. 1992; Dalziel et al. 1994; Dalziel 1997), and those models that suggest a geodynamic evolution dominated by intracrustal recycling processes with minor contributions of juvenile magmatism (Damm et al. 1990; 1994; Bock et al. 2000; Lucassen et al. 2000; Zimmermann and Bahlburg 2004).

The CIP is exposed in the southern Puna (between $25^{\circ} 00^{\prime} \mathrm{S}$ and $24^{\circ} 50^{\prime} \mathrm{S}$ and $67^{\circ} 07^{\prime} \mathrm{W}$ and $\left.67^{\circ} 00^{\prime} \mathrm{W}\right)$ and intruded into mafic to ultramafic rocks (hereafter Puna ultramafics; fig. 2). The intrusion contact between the CIP and the Puna ultramafics is marked by the occurrence of black walls (Zimmermann 1999). Their petrogenesis is related to metasomatic processes at the contact between intermediate to felsic intrusions and mafic to ultramafic host rocks (e.g., Barton et al. 1991). The black walls consist mainly of biotite and minor clinopyroxene and were used in this study, besides $\mathrm{U}-\mathrm{Pb}$ analyses of sphenes, to date the intrusive event. Early Ordovician arc activity in the Puna area is evident from the volcanosedimentary successions exposed in the northern Puna (Bahlburg 1998), from the Tollilar and Diablo formations exposed in the southern Puna (Zimmermann 1999), and from subduction-related magmatic rocks in north Chile (Choschas granodiorite in the Complejo Igneo-Sedimentario del Cordon de Lila) and in the western reaches of the southern Puna (Archibarca granite; Bahlburg and Hervé 1997).

The Puna region is of particular interest for the geodynamic evolution of the proto-Andean margin of Gondwana during the Early Paleozoic. The Puna ultramafics have been interpreted as Ordovician ophiolites representing the suture between the proposed Pampia and Arequipa-Antofalla terranes (e.g., Bahlburg and Hervé 1997). In more recent studies, a MORB-related origin of these rocks was excluded, and an island arc setting was suggested (Bahlburg et al. 1997; Coira et al. 1999; Bock et al. 2000). Due to the lack of a terrane boundary, Bahlburg et al. (2000) proposed a contiguous Arequipa-Pampia terrane. Origin and evolution of the CIP magmas, and in particular their relationship to the Famatinian

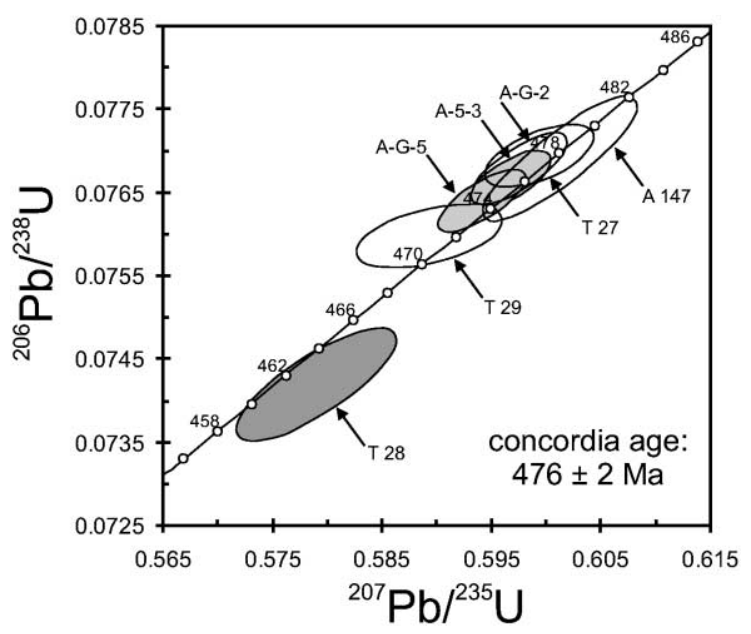

Figure 3. U-Pb concordia diagram for the intermediate Complejo Igneo Pocitos samples: light gray = Group 1; white = Group 2; dark gray = monzogranite. The sphene separates were obtained by sieving the sample through a $180-500-\mu \mathrm{m}$ fraction. They were purified by washing in deionized water, by magnetic separation, by separation by heavy liquids (bromoform-acetone), and by handpicking. The sphenes were washed in warm deionized water and $2 \mathrm{~N} \mathrm{HCl}$ to remove surface contaminations and were spiked with a mixed ${ }^{205} \mathrm{~Pb}^{235} \mathrm{U}$ spike before digesting in a 5:1 mixture of concentrated $\mathrm{HF}$ and $\mathrm{HNO}_{3}$ in 3-mL screw-top Teflon vials inside Krogh-style Teflon bombs at $180^{\circ} \mathrm{C}$ for $3 \mathrm{~d}$. 
arc in central Argentina, provide important constraints on the paleotectonic setting of the Puna ultramafic and the Paleozoic geodynamic evolution of the Puna region.

\section{Samples and Analytical Techniques}

The magmatic rocks of the CIP can be subdivided petrographically into monzodiorite, monzonite, quartz monzonite, and monzogranite. The dominant phases are hornblende, plagioclase, and alkalifeldspar. Some samples contain clinopyroxene in the matrix as well as inclusions in hornblende. Biotite is generally rare and occurs predominantly as a late growth along the rims of hornblende. Accessory phases include titanite (particularly in intermediate samples), apatite, allanite, and magnetite. Plagioclase shows typical magmatic zoning. Kfeldspar commonly displays exsolution, and some occur as microcline. All magmatic rocks show signs of low temperature alteration, particularly sericitization of feldspars and breakdown of hornblende to chlorite and epidote.

The samples were analyzed for major and trace elements by standard x-ray fluorescence (XRF) techniques at the Institut für Mineralogie und Geochemie at the University of Köln and by inductively coupled plasma mass specrometry (ICP-MS) at the Activation Laboratories, Lancaster, Ontario. For the Rb-Sr and Sm-Nd whole-rock isotope analyses, $\sim 50 \mathrm{mg}$ of the samples were spiked with a mixed ${ }^{87} \mathrm{Rb}-{ }^{84} \mathrm{Sr}$ and a mixed ${ }^{149} \mathrm{Sm}$ ${ }^{150} \mathrm{Nd}$ tracer and were digested in concentrated HF- $\mathrm{HNO}_{3}(5: 1)$ in $3-\mathrm{mL}$ screw-top Teflon vials inside Krogh-style Teflon bombs at $180^{\circ} \mathrm{C}$ for $3 \mathrm{~d}$. $\mathrm{Rb}, \mathrm{Sr}$, and rare earth elements (REE) were separated by using standard cation exchange columns with DOWEX AG $50 \mathrm{~W}$-X 8 resin. $\mathrm{Nd}$ and Sm were separated from the other REE using HDEHPcoated Teflon columns. Sr, Sm, and Nd isotope measurements were performed on a VG Sector 54 thermal ionization mass spectrometer operating in dynamic mode for $\mathrm{Sr}$ and $\mathrm{Nd}$ and in static mode for $\mathrm{Sm}$. Rb was analyzed using a Teledyne SS 1290 mass spectrometer operating in sequential mode. $\mathrm{Nd}$ and $\mathrm{Sr}$ isotopes were normalized to

Table 2. Rb-Sr Data from the Black Wall Sample

\begin{tabular}{lcccc}
\hline Sample & $\begin{array}{c}\mathrm{Rb} \\
(\mathrm{ppm})\end{array}$ & $\begin{array}{c}\mathrm{Sr} \\
(\mathrm{ppm})\end{array}$ & $\begin{array}{c}{ }^{87} \mathrm{Rb} \\
{ }^{86} \mathrm{Sr}\end{array}$ & \begin{tabular}{c}
${ }^{87} \mathrm{Sr}$ \\
\hline Biotite 1
\end{tabular}${ }^{86} \mathrm{Sr}$ \\
Biotite 2 & 248.1 & 85.93 & 23.17 & $.857552 \pm 24$ \\
Biotite 3 & 225.3 & 367.3 & 2.125 & $.719593 \pm 14$ \\
Clinopyroxene & 37.04 & 104.5 & 1.773 & $.717816 \pm 26$ \\
\hline
\end{tabular}

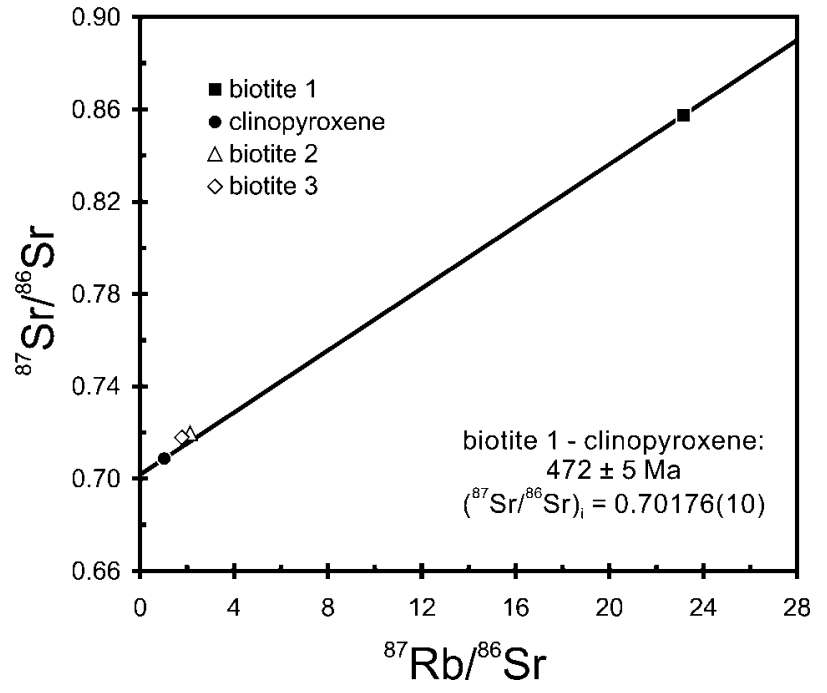

Figure 4. Rb-Sr clinopyroxene-biotite isochron. For the age calculation, only the clinopyroxene and biotite 1 data are included. The different biotites refer to different grain sizes: biotite $1 \approx 0.3 \mathrm{~cm}$; biotite $2=125-63 \mu \mathrm{m}$; biotite $3 \leq 63 \mu \mathrm{m}$. The biotites were ground under ethanol using an agate mortar. They were purified by washing in deionized water and ethanol. Clinopyroxene separates were obtained by sieving the sample through a $180-500-\mu \mathrm{m}$ mesh. They were purified by washing in deionized water and handpicking. The biotite and clinopyroxene mineral separates were spiked with a mixed ${ }^{87} \mathrm{Rb}-{ }^{84} \mathrm{Sr}$ spike and digested in hot concentrated $\mathrm{HF}_{-} \mathrm{HNO}_{3}(5: 1)$ in screwtop Teflon vials. $\mathrm{Rb}$ and $\mathrm{Sr}$ were separated by the same cation exchange techniques as described for whole-rock samples.

${ }^{146} \mathrm{Nd} /{ }^{144} \mathrm{Nd}=0.7219$ and ${ }^{86} \mathrm{Sr} /{ }^{88} \mathrm{Sr}=0.1194$. Repeated measurements of the La Jolla Nd standard and the Sr standard NBS 987 during the course of this study gave ${ }^{143} \mathrm{Nd} /{ }^{144} \mathrm{Nd}=0.511853 \pm 14(2 \sigma$, $n=8)$ and ${ }^{87} \mathrm{Sr} /{ }^{86} \mathrm{Sr}=0.710318 \pm 20(2 \sigma, n=6)$. Analytical errors in the ${ }^{87} \mathrm{Rb} /{ }^{86} \mathrm{Sr}$ and ${ }^{147} \mathrm{Sm} /{ }^{144} \mathrm{Nd}$ ratios are always smaller than $1 \%$ and $0.1 \%$, respectively. Blanks for $\mathrm{Sr}, \mathrm{Rb}, \mathrm{Nd}$, and $\mathrm{Sm}$ were estimated to be $0.2 \mathrm{ng}, 0.04 \mathrm{ng}, 0.03 \mathrm{ng}$, and 0.06 $\mathrm{ng}$, and are negligible.

For the $\mathrm{Pb}$ isotope and $\mathrm{U}-\mathrm{Pb}$ isotope analyses, separation of $\mathrm{Pb}$ was achieved using a $\mathrm{HCl}-\mathrm{HBr}$ chemistry, and $\mathrm{U}$ was separated using a $\mathrm{HCl}$ chemistry. $\mathrm{U}$ and $\mathrm{Pb}$ isotope measurements were carried out using a VG Sector 54 thermal ionization mass spectrometer in static mode. Both elements were loaded separately on Re single filaments following the $\mathrm{H}_{3} \mathrm{PO}_{4}$ silica gel method (Cameron et al. 1967). $\mathrm{U}$ and $\mathrm{Pb}$ isotope analyses were corrected for mass fractionation by a factor of $0.11 \% \pm 0.02 \%$ and $0.13 \% \pm 0.02 \%$ per amu, respectively. The repro- 
Table 3. Whole Rock Major- (in wt\%) and Trace- (in ppm) Element Composition of the Complejo Igneo Pocitos Samples

\begin{tabular}{|c|c|c|c|c|c|c|c|c|c|c|c|c|c|}
\hline \multirow[b]{2}{*}{ Sample } & \multicolumn{4}{|c|}{ Group 1} & \multicolumn{8}{|c|}{ Group 2} & \multirow[b]{2}{*}{$\mathrm{T} 28^{\mathrm{d}}$} \\
\hline & $\mathrm{T} 30^{\mathrm{a}}$ & $\mathrm{T} 105^{\mathrm{a}}$ & $A-5-3^{b}$ & A-G- $5^{b}$ & $\mathrm{~A} 147^{\mathrm{b}}$ & $\mathrm{A} 151^{\mathrm{b}}$ & $\mathrm{A} 155^{\mathrm{b}}$ & A-G-2 $2^{b}$ & $\mathrm{~T} 17^{\mathrm{c}}$ & $\mathrm{T} 18^{\mathrm{a}}$ & $\mathrm{T} 27^{\mathrm{b}}$ & $\mathrm{T} 29^{\mathrm{b}}$ & \\
\hline $\mathrm{SiO}_{2}$ & 47.8 & 49.3 & 60.4 & 59.5 & 55.4 & 58.8 & 60.9 & 58.9 & 64.8 & 48.6 & 56.8 & 60.3 & 68.4 \\
\hline $\mathrm{TiO}_{2}$ & .78 & .78 & .45 & .45 & .79 & .59 & .53 & .62 & .37 & 1.18 & .67 & .45 & .29 \\
\hline $\mathrm{Al}_{2} \mathrm{O}_{3}$ & 15.4 & 14.4 & 19.0 & 18.6 & 17.9 & 19.8 & 19.1 & 17.8 & 17.5 & 15.5 & 17.6 & 18.2 & 15.8 \\
\hline $\mathrm{FeO}_{\text {tot }}$ & 7.80 & 7.73 & 4.06 & 3.95 & 6.04 & 4.54 & 3.57 & 4.95 & 2.29 & 7.28 & 5.14 & 2.96 & 2.62 \\
\hline $\mathrm{MnO}$ & .16 & .18 & .11 & .11 & .14 & .10 & .10 & .11 & .05 & .16 & .12 & .09 & .10 \\
\hline $\mathrm{MgO}$ & 9.16 & 9.50 & 1.69 & 1.72 & 3.00 & 2.09 & .89 & 2.46 & .54 & 8.46 & 2.69 & .96 & .90 \\
\hline $\mathrm{CaO}$ & 10.5 & 9.52 & 4.35 & 4.20 & 5.55 & 5.77 & 3.28 & 5.07 & 2.33 & 10.1 & 5.56 & 2.67 & 1.54 \\
\hline $\mathrm{Na}_{2} \mathrm{O}$ & 1.99 & 2.25 & 4.82 & 4.90 & 5.27 & 3.12 & 4.23 & 5.28 & 5.22 & 3.02 & 5.04 & 4.32 & 6.59 \\
\hline $\mathrm{K}_{2} \mathrm{O}$ & 2.00 & 2.06 & 4.75 & 4.67 & 3.80 & 5.25 & 6.59 & 3.75 & 5.21 & 2.46 & 3.7 & 7.41 & 3.13 \\
\hline $\mathrm{P}_{2} \mathrm{O}_{5}$ & .24 & .21 & .3 & .3 & .51 & .3 & .17 & .36 & .09 & .41 & .4 & .16 & .16 \\
\hline L.O.I. & 3.07 & 2.69 & .54 & .99 & 1.01 & .6 & .36 & .61 & .49 & 1.48 & .79 & .79 & 1.19 \\
\hline Total & 98.9 & 98.6 & 100.5 & 99.3 & 99.5 & 101 & 99.8 & 99.9 & 98.8 & 98.5 & 98.6 & 98.4 & 100.8 \\
\hline $\mathrm{Sc}$ & 35 & 28 & 9 & 10 & 17 & 12 & 9 & 13 & n.a. & 31 & 10 & n.a. & n.a. \\
\hline $\mathrm{V}$ & 252 & 213 & 101 & 100 & 172 & 123 & 89 & 125 & 48 & 265 & 151 & 76 & 57 \\
\hline $\mathrm{Cr}$ & 392 & 412 & n.a. & 46 & 25 & 28 & 10 & 30 & n.a. & 299 & 30 & 19 & n.a. \\
\hline $\mathrm{Ni}$ & 144 & 160 & 9 & 10 & 14 & 13 & 5 & 13 & 8 & 147 & 13 & 10 & 4 \\
\hline $\mathrm{Sr}$ & 809 & 682 & 1870 & 1760 & 1010 & 1094 & 1703 & 899 & 897 & 921 & 1080 & 846 & 973 \\
\hline $\mathrm{Y}$ & 22 & 23.4 & 22.3 & 20.3 & 35.1 & 21 & 30 & 33 & 30.2 & 30 & 33.5 & 27 & 15.8 \\
\hline $\mathrm{Zr}$ & 113 & 127 & 450 & 427 & 450 & 322 & 533 & 424 & 509 & 194 & 477 & 493 & 237 \\
\hline $\mathrm{Nb}$ & n.a. & 24.5 & 39.1 & 34.7 & 41 & 12 & 20 & 20 & 41.4 & 25.7 & 33.8 & 21 & 37.7 \\
\hline Cs & n.a. & 5.3 & 4.9 & 5.8 & 17 & n.a. & n.a. & n.a. & 5.9 & 8.6 & 7.9 & n.a. & 7.2 \\
\hline $\mathrm{Ba}$ & 512 & 668 & 2310 & 2180 & 1250 & 850 & 1939 & 1137 & 1600 & 1210 & 1310 & 892 & 1270 \\
\hline $\mathrm{Hf}$ & n.a. & 3.33 & 8.62 & 8.22 & 10.3 & n.a. & n.a. & n.a. & 11.2 & 4.88 & 10.2 & n.a. & 5.27 \\
\hline $\mathrm{Pb}$ & n.a. & 9 & 23 & 17 & 54 & n.a. & n.a. & n.a. & 39 & 9 & 35 & n.a. & 36 \\
\hline Th & 17 & 13.1 & 54.9 & 46.3 & 89.6 & 43 & 64 & 67 & 42.7 & 21.3 & 50.0 & 58 & 74.4 \\
\hline $\mathrm{U}$ & 11 & 3.48 & 6.86 & 7.18 & 20.5 & 17 & 20 & 18 & 11.7 & 5.35 & 10.2 & 16 & 11 \\
\hline $\mathrm{La}$ & n.a. & 39.5 & 195 & 169 & 193 & n.a. & n.a. & n.a. & 141 & 69.9 & 137 & n.a. & 130 \\
\hline $\mathrm{Ce}$ & n.a. & 95.7 & 312 & 271 & 333 & n.a. & n.a. & n.a. & 231 & 143 & 272 & n.a. & 205 \\
\hline $\mathrm{Pr}$ & n.a. & 11.7 & 28.7 & 25.0 & 33.2 & n.a. & n.a. & n.a. & 21.7 & 16.5 & 27.3 & n.a. & 18.5 \\
\hline $\mathrm{Nd}$ & n.a. & 47.0 & 91.9 & 79.2 & 113 & n.a. & n.a. & n.a. & 69.8 & 65.5 & 97.2 & n.a. & 58.9 \\
\hline $\mathrm{Sm}$ & n.a. & 8.13 & 11.3 & 9.85 & 16.7 & n.a. & n.a. & n.a. & 10.2 & 11.8 & 14.8 & n.a. & 7.18 \\
\hline $\mathrm{Eu}$ & n.a. & 2.15 & 2.88 & 2.6 & 3.27 & n.a. & n.a. & n.a. & 2.26 & 2.67 & 3.07 & n.a. & 1.81 \\
\hline $\mathrm{Gd}$ & n.a. & 5.89 & 8.83 & 8.16 & 12.7 & n.a. & n.a. & n.a. & 7.96 & 8.86 & 10.6 & n.a. & 5.41 \\
\hline $\mathrm{Tb}$ & n.a. & .81 & .9 & .81 & 1.39 & n.a. & n.a. & n.a. & 1.05 & 1.17 & 1.27 & n.a. & .57 \\
\hline Dy & n.a. & 4.27 & 4.08 & 3.67 & 6.56 & n.a. & n.a. & n.a. & 5.23 & 5.69 & 6.03 & n.a. & 2.8 \\
\hline $\mathrm{Tm}$ & n.a. & .35 & .29 & .28 & .44 & n.a. & n.a. & n.a. & .42 & .36 & .44 & n.a. & .21 \\
\hline $\mathrm{Yb}$ & n.a. & 2.28 & 1.93 & 1.87 & 2.76 & n.a. & n.a. & n.a. & 2.91 & 2.23 & 2.91 & n.a. & 1.4 \\
\hline $\mathrm{Lu}$ & n.a. & .33 & .25 & .25 & .37 & n.a. & n.a. & n.a. & .43 & .31 & .4 & n.a. & .21 \\
\hline $\mathrm{La}_{\mathrm{N}} / \mathrm{Yb}_{\mathrm{N}}$ & & 11.7 & 68.1 & 60.8 & 47.2 & & & & 32.8 & 21.1 & 31.8 & & 62.9 \\
\hline
\end{tabular}

Note. Major elements, Sc, and Ni were analyzed using x-ray fluorescence (XRF). For selected samples, trace elements were analyzed using inductively coupled plasma mass spectrometry. For samples that were not analyzed for rare earth elements, trace element data determined using XRF are reported. n.a. = not analyzed; L.O.I. = loss on ignition.

${ }^{a}$ Monzodiorite.

b Monzonite.

${ }^{c}$ Quartz-monzonite.

d Monzogranite.

ducibility of the $\mathrm{Pb}$ standard NBS 982 was estimated to be $0.04 \%, 0.06 \%, 0.07 \%$, and $0.02 \%$ for the ${ }^{206} \mathrm{~Pb} / 2{ }^{204} \mathrm{~Pb},{ }^{207} \mathrm{~Pb} /{ }^{204} \mathrm{~Pb},{ }^{208} \mathrm{~Pb} /{ }^{204} \mathrm{~Pb}$, and ${ }^{207} \mathrm{~Pb} /$ ${ }^{206} \mathrm{~Pb}$ ratios, respectively. Run-to-run uncertainties in the $\mathrm{U} / \mathrm{Pb}$ ratios were estimated to be $0.3 \%$. The total procedural blanks for $\mathrm{Pb}$ and $\mathrm{U}$ were $20-70 \mathrm{pg}$ and $2 \mathrm{pg}$, respectively. Measured $\mathrm{Pb}$ ratios for the blank are ${ }^{206} \mathrm{~Pb} /{ }^{204} \mathrm{~Pb}=18.36,{ }^{207} \mathrm{~Pb} /{ }^{204} \mathrm{~Pb}=15.72$, and ${ }^{208} \mathrm{~Pb} /{ }^{204} \mathrm{~Pb}=38.31$. A blank correction for $\mathrm{Pb}$ was insignificant for the Pb-rich K-feldspars. The uncertainties for the $\mathrm{U} / \mathrm{Pb}$ and ${ }^{207} \mathrm{~Pb} /{ }^{206} \mathrm{~Pb}$ ratios and ages were calculated according to the method of Ludwig (1991). They include the reproducibility of the standard, common $\mathrm{Pb}$ and blank corrections as well as within-run uncertainties and the uncertainties in the $\mathrm{U} / \mathrm{Pb}$ ratio of the spike.

\section{Geochronological Results}

$\mathrm{U}-\mathrm{Pb}$ analyses on sphenes from the intermediate to felsic samples are summarized in table 1 and figure 3. For samples with low ${ }^{206} \mathrm{~Pb} /{ }^{204} \mathrm{~Pb}$ ratios, the effect of the corrections for common $\mathrm{Pb}$ on the calculated ages is significant. Therefore, it is critical to know the appropriate isotope composition of the common $\mathrm{Pb}$ component very precisely. Leaching $\mathrm{K}$ feldspars with HF has been shown to remove its radiogenic $\mathrm{Pb}$ component, so that the $\mathrm{Pb}$ isotope composition of leached K-feldspar should be approximately identical to the initial $\mathrm{Pb}$ isotope composition of the K-feldspars at the time of its closure (e.g., Ludwig and Silver 1977). Therefore, the Pb isotope composition of coexisting K-feldspars can 
Table 4. Rb-Sr and Sm-Nd Whole-Rock Isotopic Data

\begin{tabular}{|c|c|c|c|c|c|c|c|c|c|c|c|c|}
\hline Sample & $\begin{array}{c}\mathrm{Sr} \\
(\mathrm{ppm})\end{array}$ & $\begin{array}{c}\mathrm{Rb} \\
(\mathrm{ppm})\end{array}$ & $\begin{array}{c}\mathrm{Sm} \\
(\mathrm{ppm})\end{array}$ & $\begin{array}{c}\mathrm{Nd} \\
(\mathrm{ppm})\end{array}$ & $\frac{{ }^{87} \mathrm{Rb}}{{ }^{86} \mathrm{Sr}}$ & $\begin{array}{c}\frac{{ }^{87} \mathrm{Sr}}{{ }^{86} \mathrm{Sr}} \\
\text { measured }\end{array}$ & $\begin{array}{l}{ }^{{ }^{87} \mathrm{Sr}} \\
{ }^{87} \mathrm{Sr} \\
\text { initial }\end{array}$ & $\frac{{ }^{147} \mathrm{Sm}}{{ }^{144} \mathrm{Nd}}$ & $\begin{array}{c}\frac{{ }^{143} \mathrm{Nd}}{{ }^{144} \mathrm{Nd}} \\
\text { measured }\end{array}$ & $\begin{array}{l}\frac{{ }^{143} \mathrm{Nd}}{{ }^{144} \mathrm{Nd}} \\
\text { initial }\end{array}$ & $\begin{array}{l}\epsilon(\mathrm{Nd}) \\
\text { initial }\end{array}$ & $\begin{array}{l}\mathrm{T}_{\mathrm{DM}} \\
\text { (Ma) }\end{array}$ \\
\hline A 147 & 989.4 & 254 & & 93.17 & .744 & $.710696 \pm 9$ & .705651 & .09012 & $.512312 \pm 6$ & .512031 & .1 & $\begin{array}{r}1007 \\
984\end{array}$ \\
\hline A 151 & 1156 & 144 & 7.61 & 51.29 & .359 & $.707709 \pm 9$ & .705272 & .08972 & $.512312 \pm 8$ & .512032 & .0 & 1004 \\
\hline A 155 & 1701 & 221 & 16.3 & 119.8 & .376 & $.708064 \pm 11$ & .705514 & 08247 & $.512320 \pm 7$ & .512063 & .7 & 941 \\
\hline A-G-2 & 906.2 & 210 & 13.2 & & .672 & $.710138 \pm 9$ & .705583 & 60 & $319 \pm 8$ & 2046 & .4 & 97 \\
\hline $\mathrm{T} 17$ & 882.2 & 203 & $\begin{array}{l}8.74 \\
8.69\end{array}$ & $\begin{array}{l}60.37 \\
60.85\end{array}$ & .667 & $.710275 \pm 12$ & .705748 & $\begin{array}{l}.08751 \\
.08635\end{array}$ & $\begin{array}{l}.512256 \pm 8 \\
.512265 \pm 8\end{array}$ & $\begin{array}{l}.511983 \\
.511996\end{array}$ & $\begin{array}{l}-.8 \\
-.6\end{array}$ & $\begin{array}{l}1052 \\
1032\end{array}$ \\
\hline Т 18 & 904.9 & 171 & 10.1 & 56.17 & .548 & $.709558 \pm 12$ & .705841 & .1089 & $.512370 \pm 8$ & .512030 & .1 & 1100 \\
\hline Т 27 & 1024 & 203 & 11 & & .574 & $.709474 \pm 10$ & .705585 & 79 & $297 \pm 7$ & 2020 & -.1 & 1014 \\
\hline Г 29 & 873.2 & 194 & 11 & 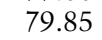 & .644 & $.709768 \pm 9$ & .705398 & .08996 & $.512314 \pm 15$ & .512033 & .2 & 100 \\
\hline A-G-5 & 1724 & 152 & $9 .($ & 1 & .255 & $.705657 \pm 8$ & .703928 & .07620 & $.512385 \pm 8$ & .512147 & 2.4 & 82 \\
\hline \multirow{2}{*}{ A-5-3 } & 1799 & 140 & 10.9 & 4 & .227 & $.705431 \pm 16$ & .703893 & .07862 & $.512408 \pm 8$ & .512163 & 2.7 & 81 \\
\hline & 1807 & 138 & & & .221 & $.705405 \pm 21$ & .703904 & & $.512400 \pm 8$ & & 2.5 & 82 \\
\hline Т 30 & 825.8 & 111 & & & .388 & $.706832 \pm 9$ & & & $2 \pm 12$ & 41 & 2.3 & 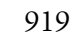 \\
\hline \multirow[t]{2}{*}{ T 105} & 669.4 & 103 & & 6 & .447 & $.707024 \pm 9$ & .76 & .1 & $.512451 \pm 9$ & .512129 & & \\
\hline & 670.6 & 103 & & 40.10 & .444 & $.707010 \pm 12$ & .703999 & .1033 & $.512461 \pm 9$ & .512139 & 2.2 & 92 \\
\hline \multirow[t]{2}{*}{ Т 28} & 1005 & 298 & 6.16 & 49.46 & .859 & $.709361 \pm 10$ & .703534 & .07523 & $.512375 \pm 9$ & .512140 & 2.3 & 834 \\
\hline & & & 6.26 & 49.89 & & & & .07583 & $.512358 \pm 9$ & .512122 & 1.9 & \\
\hline
\end{tabular}

Note. $\epsilon(\mathrm{Nd})$ at the time of intrusion $(476 \mathrm{Ma})$ are calculated relative to chondrite uniform reservoir with present-day values of ${ }^{143} \mathrm{Nd} /{ }^{144} \mathrm{Nd}=0.512638$ and ${ }^{147} \mathrm{Sm} /{ }^{144} \mathrm{Nd}=0.1967$ (Jacobsen and Wasserburg 1960). Nd model ages are calculated with a depletedmantle reservoir and present-day values of ${ }^{143} \mathrm{Nd} /{ }^{144} \mathrm{Nd}=0.51315$ and ${ }^{147} \mathrm{Sm} /{ }^{144} \mathrm{Nd}=0.217$ (Goldstein et al. 1984).

be used for the common $\mathrm{Pb}$ corrections. All analyzed sphenes except those from sample $\mathrm{T} 28$ gave concordant ages resulting in a concordia age of $476 \pm 2 \mathrm{Ma}$. This age is identical to the ${ }^{207} \mathrm{~Pb} /{ }^{206} \mathrm{~Pb}$ age of sample $\mathrm{T} 28$, which is considered to be slightly discordant due to recent $\mathrm{Pb}$ loss (fig. 3). Therefore, this sample is not included in the calculation of the concordia age. The $\mathrm{U}-\mathrm{Pb}$ age of $476 \pm 2 \mathrm{Ma}$ is interpreted to be the time of intrusion of the CIP and is identical to but of higher precision than previously reported $\mathrm{K}-\mathrm{Ar}$ ages of $494 \pm 20 \mathrm{Ma}$ for an amphibole separate and $470 \pm 17 \mathrm{Ma}$ for a biotite-amphibole separate for monzonites of the CIP (Blasco et al. 1996).

$\mathrm{Rb}-\mathrm{Sr}$ data for biotite and clinopyroxene separates from the black wall sample are listed in table 2 and shown in figure 4 . The black wall sample mainly consists of coarse biotite grains $(0.5-1 \mathrm{~cm}$ in length) surrounded by fine-grained biotites. Separates of both fractions were analyzed for their $\mathrm{Rb}$ $\mathrm{Sr}$ systematics. A clinopyroxene separate and a coarse-grained biotite (biotite 1) define an isochron corresponding to an age of $472 \pm 5 \mathrm{Ma}$ (fig. 4). This age is identical to the U-Pb sphene age. The two fine-grained biotite separates (biotites 2 and 3) do not plot on the isochron. Compared to biotite 1, they display much lower $\mathrm{Rb} / \mathrm{Sr}$ ratios, most likely indicating interaction with a fluid phase enriched in $\mathrm{Sr}$. This interaction possibly changed the $\mathrm{Rb} / \mathrm{Sr}$ ratio and the $\mathrm{Sr}$ isotope composition resulting in an offset from the isochron.

The low initial ${ }^{87} \mathrm{Sr} /{ }^{86} \mathrm{Sr}$ of $0.70176 \pm 0.00010$ from the black wall isochron provides important information about the age of the Puna ultramafics in which the CIP intruded. The isotope composition of the black wall can be considered as a mixture of material from the CIP and the surrounding crust. Because the initial ${ }^{87} \mathrm{Sr} /{ }^{86} \mathrm{Sr}$ of the black wall is significantly lower than those for the CIP of 0.704-0.706, the Puna ultramafics must have a ${ }^{87} \mathrm{Sr} /{ }^{86} \mathrm{Sr}$ ratio at $476 \mathrm{Ma}$ that was significantly lower than the initial ratio of the black wall. Such low ${ }^{87} \mathrm{Sr}{ }^{86} \mathrm{Sr}$ values can only be maintained in old crustal domains with low $\mathrm{Rb} / \mathrm{Sr}$ ratios, indicating that the Puna ultramafics in which the CIP intruded is of Proterozoic age. This result is consistent with the interpretation of structural data that indicate a Precambrian age (Mon and Hongn 1991). The Puna ultramafics, therefore, cannot represent Ordovician ophiolithes, indicating that there is no terrane boundary between the Pampia and Arequipa-Antofalla crustal blocks. These results provide strong support for the interpretation of Bahlburg et al. (2000), who proposed a contiguous Arequipa-Pampia terrane.

\section{Major and Trace Element and Sr-Nd-Pb Isotope Composition}

Major and trace element analyses and $\mathrm{Sr}-\mathrm{Nd}-\mathrm{Pb}$ isotope data for the CIP rocks are listed in tables 35. $\mathrm{SiO}_{2}$ contents are consistent with the modal compositions of the examined samples and show the division into monzodiorites and more evolved rocks comprising monzonites and monzogranites. All samples are metaluminous with an alumina 
Table 5. $\mathrm{Pb}$ Isotope Data of Leached K-Feldspar

\begin{tabular}{lccc}
\hline & ${ }^{206} \mathrm{~Pb}$ & ${ }^{207} \mathrm{~Pb}$ & \\
Sample & $\frac{{ }^{208} \mathrm{~Pb}}{{ }^{204} \mathrm{~Pb}}$ & ${ }^{204} \mathrm{~Pb}$ & ${ }^{204} \mathrm{~Pb}$ \\
\hline A 147 & 18.34 & 15.62 & 38.06 \\
& 18.33 & 15.61 & 38.02 \\
A 155 & 18.48 & 15.61 & 38.11 \\
A-G-2 & 18.44 & 15.62 & 38.10 \\
T 17 & 18.54 & 15.62 & 38.12 \\
& 18.54 & 15.62 & 38.13 \\
T 18 & 18.42 & 15.62 & 38.10 \\
T 27 & 18.50 & 15.61 & 38.15 \\
T 29 & 18.56 & 15.63 & 38.19 \\
A-G-5 & 18.48 & 15.60 & 38.13 \\
A-5-3 & 18.45 & 15.61 & 38.12 \\
T 30 & 18.45 & 15.64 & 38.18 \\
& 18.43 & 15.64 & 38.16 \\
T 105 & 18.45 & 15.64 & 38.19 \\
& 18.45 & 15.64 & 38.20 \\
T 28 & 18.55 & 15.62 & 38.25 \\
\hline Note. The &
\end{tabular}

Note. The K-feldspar separates were obtained by sieving the sample through a $180-500-\mu \mathrm{m}$ fraction. They were purified by washing in deionized water, by magnetic separation, by separation by heavy liquids (bromoform-acetone), and by handpicking. The K-feldspars were washed in warm aqua regia, leached twice in $\mathrm{H}_{2} \mathrm{O}-\mathrm{HF}$ mixtures, and dissolved in concentrated HF.

saturation index (A.S.I. $=$ molar $\mathrm{Al}_{2} \mathrm{O}_{3} / \mathrm{Na}_{2} \mathrm{O}+$ $\left.\mathrm{CaO}+\mathrm{K}_{2} \mathrm{O}\right)<1$. The molar ratio of $\mathrm{Al}_{2} \mathrm{O}_{3} /$ $\mathrm{Na}_{2} \mathrm{O}+\mathrm{K}_{2} \mathrm{O}>1$ classifies the examined samples as calc-alkaline rocks. In general, $\mathrm{MgO}, \mathrm{FeO}_{\text {total, }}$ $\mathrm{TiO}_{2}$, and $\mathrm{CaO}$ decrease with increasing $\mathrm{SiO}_{2}$ while $\mathrm{K}_{2} \mathrm{O}$ and $\mathrm{Na}_{2} \mathrm{O}$ increase. All CIP rocks show similar trace element patterns with a strong enrichment in incompatible elements and pronounced negative $\mathrm{Nb}$ and $\mathrm{Ti}$ as well as positive $\mathrm{Pb}$ anomalies (fig. 5). The mafic samples display the highest contents in compatible elements (Sc, V, Cr, Ni) and are less enriched in most incompatible elements compared to the more evolved rocks. Despite the above outlined similarities, differences in the major and trace element characteristics can be observed between the two CIP suites (the distinction between two groups is based on Sr-Nd isotopes and is discussed below). Differences in the fractionation behavior are evident from different positions and slopes in plots of $\mathrm{P}_{2} \mathrm{O}_{5}, \mathrm{TiO}_{2}$, and Th versus $\mathrm{SiO}_{2}, \mathrm{Al}_{2} \mathrm{O}_{3}$ versus $\mathrm{CaO}$, and $\mathrm{Sc}$ versus $\mathrm{V}$ (fig. 6). Additionally, fractionation of the REE is more pronounced in group 1 samples with $\mathrm{La}_{\mathrm{N}} / \mathrm{Yb}_{\mathrm{N}}$ ratios from $\sim 12$ for a monzodiorite to $\sim 68$ for the most evolved monzonite. $\mathrm{La}_{\mathrm{N}} / \mathrm{Yb}_{\mathrm{N}}$ ratios in group 2 samples first increase from $\sim 21$ for the monzodiorite to $\sim 47$ for the less evolved monzonite and then decrease again to values around 32 for the more evolved monzonites. Furthermore, at a given $\mathrm{SiO}_{2}$ content, group 2 samples tend to have higher contents of most of the incompatible trace elements than rocks from group 1.
Based on $\mathrm{Sr}$ and $\mathrm{Nd}$ isotope data back-calculated to $476 \mathrm{Ma}$, the samples can be subdivided into two groups, both comprising mafic and more evolved rocks. Samples from group 1 display homogeneous initial ${ }^{87} \mathrm{Sr} /{ }^{86} \mathrm{Sr}$ ratios ranging from 0.7039 to 0.7042 and homogeneous initial $\epsilon_{\mathrm{Nd}}$ values between 2.2 and 2.7. Group 2 rocks are characterized by initial ${ }^{87} \mathrm{Sr} /$ ${ }^{86} \mathrm{Sr}$ ratios between 0.7053 and 0.7058 and initial $\epsilon_{\mathrm{Nd}}$ values ranging from 0.8 to 0.7 . Sample T 28 is distinct from these two groups and displays the least radiogenic $S r$ isotope composition and $\epsilon_{\mathrm{Nd}}$ values similar to those of group 1, and, consequently, can be considered to represent a third group. However, because this possible third group is only represented by one sample, it will not be discussed in further detail. Despite the differences in the Sr and $\mathrm{Nd}$ isotope compositions, all CIP rocks show a narrow range in their initial $\mathrm{Pb}$ isotope composition, with ${ }^{206} \mathrm{~Pb} /{ }^{204} \mathrm{~Pb},{ }^{207} \mathrm{~Pb} /{ }^{204} \mathrm{~Pb}$, and ${ }^{208} \mathrm{~Pb} /{ }^{204} \mathrm{~Pb}$ ratios ranging from 18.34 to $18.59,15.6$ to 15.64 , and 38.06 to 38.25 .

Key observations that need to be explained by any successful model for the petrogenesis of the CIP include (1) the similarity in major and trace element composition of all examined samples indicating a cogenetic origin, (2) the development of two distinct parental magmas as evident from differences in the initial $\mathrm{Sr}$ and $\mathrm{Nd}$ isotope compositions, and (3) the remarkably homogeneous isotopic composition within each group. Further important features are the high degree of enrichment of the incompatible trace elements at $\mathrm{SiO}_{2}$ contents as low as $48 \mathrm{wt} \%$ and the observed higher contents of most of the incompatible trace elements in group 2 samples at a given $\mathrm{SiO}_{2}$.

\section{Discussion}

The $\mathrm{Sr}$ and $\mathrm{Nd}$ isotope systematics indicate the contribution of mantle and crustal sources to the generation of the CIP magmas (fig. 7). Hence, $\mathrm{Nd}$ model ages of the CIP rocks cannot be interpreted as real crust formation ages but nevertheless provide a lower limit for the age of the crustal component. The $\mathrm{Nd}$ model ages for the CIP range from 800 to $1100 \mathrm{Ma}$, indicating a Proterozoic age for the crustal sources. In the ${ }^{207} \mathrm{~Pb} /{ }^{204} \mathrm{~Pb}-{ }^{206} \mathrm{~Pb} /{ }^{204} \mathrm{~Pb}$ diagram, the examined samples intersect the Stacey and Kramers (1975) Pb evolution curve at younger ages than indicated by the U-Pb crystallization age for the CIP (fig. 8). In combination with the $\mathrm{Nd}$ model ages, this indicates incorporation of a most likely Middle Proterozoic crustal component. This interpretation is consistent with the remarkably low initial ${ }^{87} \mathrm{Sr} /{ }^{86} \mathrm{Sr}$ of the black wall rocks, which 


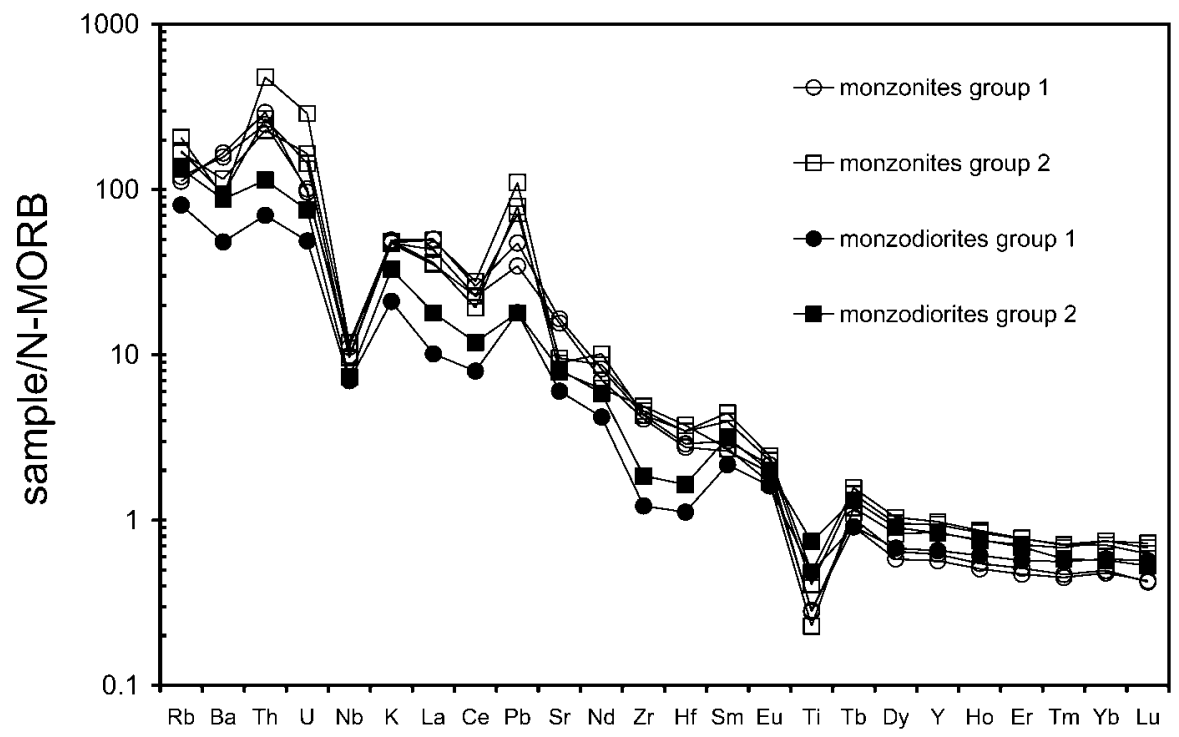

Figure 5. The normal-MORB-normalized trace element plots for selected samples from the Complejo Igneo Pocitos. Normalizing factors according to Hofmann (1988).

also suggests a Proterozoic age for the crust into which the CIP intruded. Some models for the Early Paleozoic geodynamic evolution of the protoAndean margin of Gondwana in the area of the southern central Andes propose a continentcontinent collision between Gondwana and Laurentia (Dalla Salda et al. 1992; Dalziel et al. 1994). Based on the $\mathrm{Pb}$ isotope data for the CIP and the Andean crust (F. Lucassen, pers. comm.), this is unlikely, because the ${ }^{207} \mathrm{~Pb} /{ }^{204} \mathrm{~Pb}$ ratio of the CIP and the Andean crust are more radiogenic than the Southern Grenville Province of North America (fig. 8). The crustal component in the CIP magmas is significantly older than the formation age of the Southern Grenville Province.

Mixing of mantle and crustal sources most likely can be attributed to the generation of the CIP magmas in a subduction-zone setting. This interpretation is consistent with the trace element compositions (most notably the strong enrichment of incompatible elements at low $\mathrm{SiO}_{2}$ contents) and the occurrence of primary hornblende. Due to the involvement of a fluid phase, subduction-related magmas are characterized by elevated $\mathrm{f}_{\mathrm{O}_{2}}$ and $\mathrm{p}_{\mathrm{H}_{2} \mathrm{O}}$ values resulting in the stabilization of hornblende (Gill 1981; Sisson and Grove 1993a, 1993b). Possible magmatic sources in arc-related magmas include the mantle wedge (most likely similar to the source of MORB), MORB-derived fluids, subducted sediments, and continental crust that may be assimilated during magma ascent (e.g., Arculus and Powell 1986; Ellam and Hawkesworth 1988;
Hildreth and Moorbath 1988; Pearce and Peate 1995; Johnson and Plank 1999). The trace element and isotope composition of the CIP is evaluated below to estimate the contributions of these different sources. The role of fractional crystallization and crustal assimilation is compared to contamination of the subarc mantle source by MORBderived fluids and subducted sediments. These results are then combined in a petrogenetic model in which the contribution of the different sources is quantified by multicomponent modeling.

Fractional Crystallization and Crustal Assimilation Processes. A general fractional crystallization trend is indicated by decreasing $\mathrm{FeO}_{\text {total }}, \mathrm{MgO}, \mathrm{CaO}$, $\mathrm{Sc}, \mathrm{V}, \mathrm{Cr}$, and $\mathrm{Ni}$ contents with increasing $\mathrm{SiO}_{2}$, indicating fractionation of hornblende and/or clinopyroxene. Hornblende is probably the major fractionating phase due to its high modal content in the CIP rocks. Decreasing $\mathrm{TiO}_{2}$ contents with increasing $\mathrm{SiO}_{2}$ (fig. 6) suggests magnetite fractionation and supports the classification as calc-alkaline rocks, where magnetite fractionation controls the $\mathrm{TiO}_{2}$ trends. For the differentiated rocks from group 2 , additional fractionation of apatite and plagioclase is evident from decreasing $\mathrm{P}_{2} \mathrm{O}_{5}, \mathrm{CaO}$, and $\mathrm{Al}_{2} \mathrm{O}_{3}$ contents with increasing $\mathrm{SiO}_{2}$ (fig. 6). In contrast, increasing $\mathrm{Sr}$ and $\mathrm{Ba}$ contents with increasing $\mathrm{SiO}_{2}$ content (not shown in fig. 6) rule out significant plagioclase fractionation in the evolution of group 1 samples. Abundances of the light rare earth element (LREE) increase with increasing $\mathrm{SiO}_{2}$ for group 1 samples most likely indicating fractiona- 

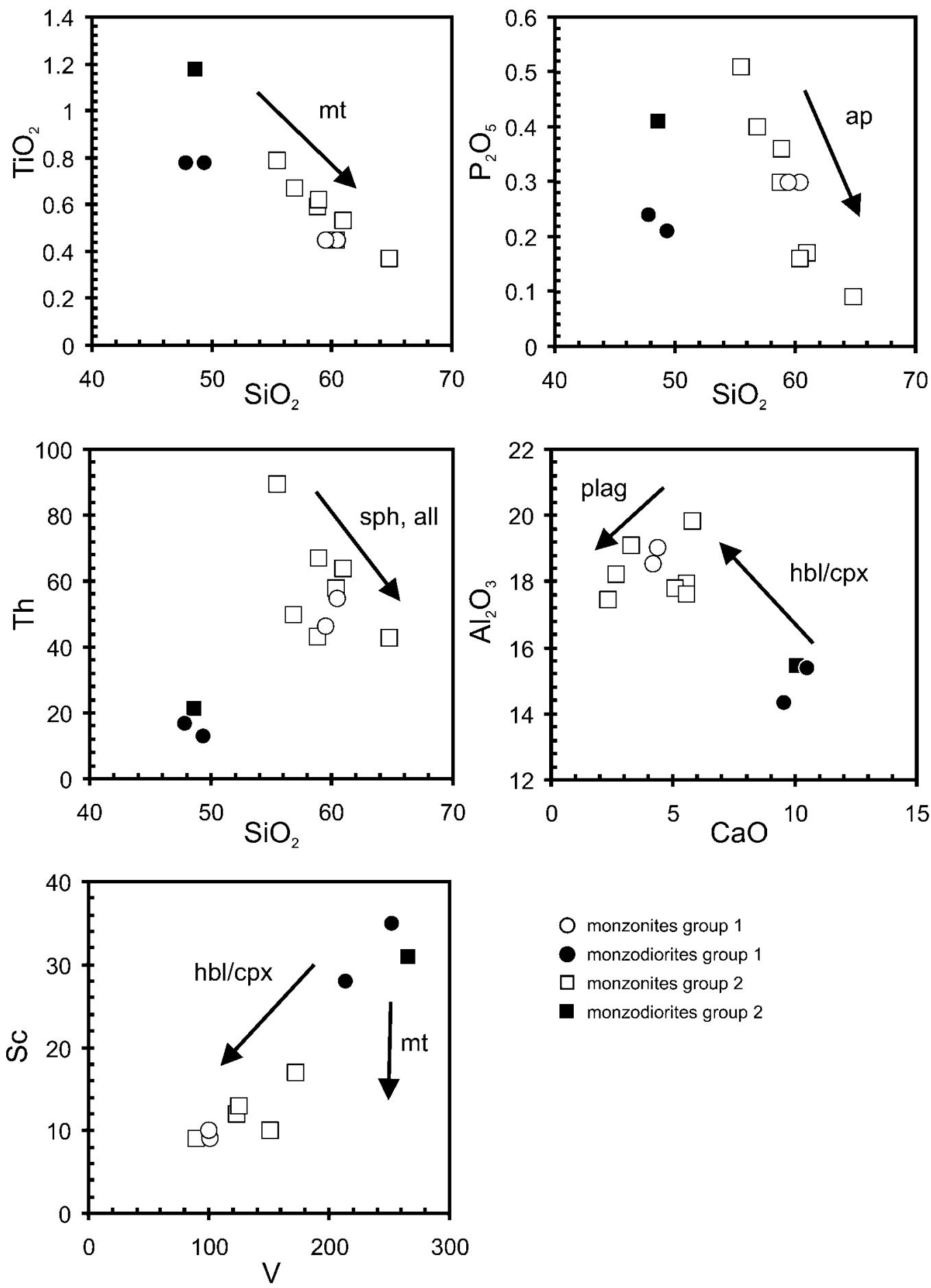

monzonites group 1

monzodiorites group 1

$\square$ monzonites group 2

monzodiorites group 2

Figure 6. Selected major and trace element plots for the two Complejo Igneo Pocitos groups. Arrows indicate schematic fractional crystallization trends. $m t=$ magnetite; $a p=$ apatite; $h b l=$ hornblende; $c p x=$ clinopyroxene; $s p h=$ sphene; $a l l=$ allanite. 


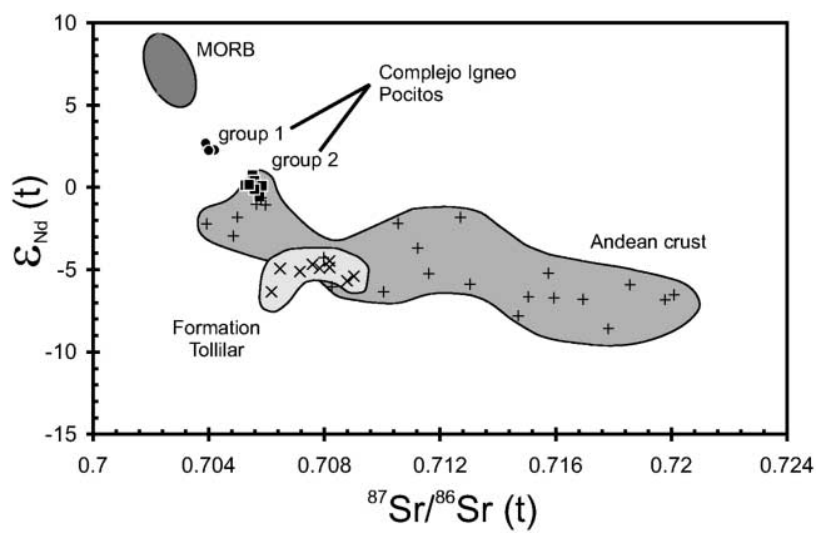

Figure 7. Plot of $\varepsilon_{\mathrm{Nd}}$ versus ${ }^{87} \mathrm{Sr} /{ }^{86} \mathrm{Sr}$ for the Complejo Igneo Pocitos (CIP) rocks at the time of intrusion $(476$ $\mathrm{Ma}$. Data fields from mid-ocean ridge basalt (MORB; Hofmann 1997), the Andean crust (F. Lucassen, pers. comm.), and the formation Tollilar (Zimmermann 1999) are shown for comparison. Based on their Sr and Nd isotope composition, the CIP samples can be divided into two groups. Both suites are intermediate in their $\mathrm{Sr}$ and $\mathrm{Nd}$ isotope composition between MORB and Andean crust, indicating mixing between these components.

tion of hornblende. The same trend can be observed for the monzodiorite and the less evolved monzonite (sample A 147) from group 2. With further increasing $\mathrm{SiO}_{2}$, LREE contents decrease in group 2 samples due to fractionation of a LREE-enriched phaselike sphene or apatite (Miller and Mittlefehlt 1982).

Correlations of $\mathrm{Sr}$ and $\mathrm{Nd}$ isotope ratios with $\mathrm{SiO}_{2}$ are useful in constraining the nature and extent of crustal assimilation processes. The combination of fractional crystallization and crustal assimilation in shallow crustal niveaus (AFC; DePaolo 1981) is expected to result in rising ${ }^{87} \mathrm{Sr} /$ ${ }^{86} \mathrm{Sr}$ ratios and decreasing $\epsilon_{\mathrm{Nd}}$ values with increasing $\mathrm{SiO}_{2}$ content (DePaolo 1981), as indicated by schematic arrows in figure 9. Despite the large range in bulk compositions from $48 \%-65 \% \mathrm{SiO}_{2}$, both CIP suites display no variation in their $\mathrm{Sr}$ and $\mathrm{Nd}$ isotope compositions (fig. 9), and, consequently, significant crustal assimilation processes in shallow levels can be ruled out. The two CIP suites, therefore, acquired their distinct and homogeneous isotope composition during deep crustal or mantle magmatic processes. This interpretation is further supported by similarities between both groups in (1) the general fractional crystallization behavior, (2) the trace element distribution, (3) the range in $\mathrm{SiO}_{2}$ contents, and (4) the phenocryst assemblages and textures.
In contrast to AFC processes, crustal assimilation by melting, assimilation, storage, and homogenization in deep crustal zones (MASH; Hildreth and Moorbath 1988) results in parental magmas with a distinct and homogeneous isotope composition. In order to evaluate the role of such MASH processes,
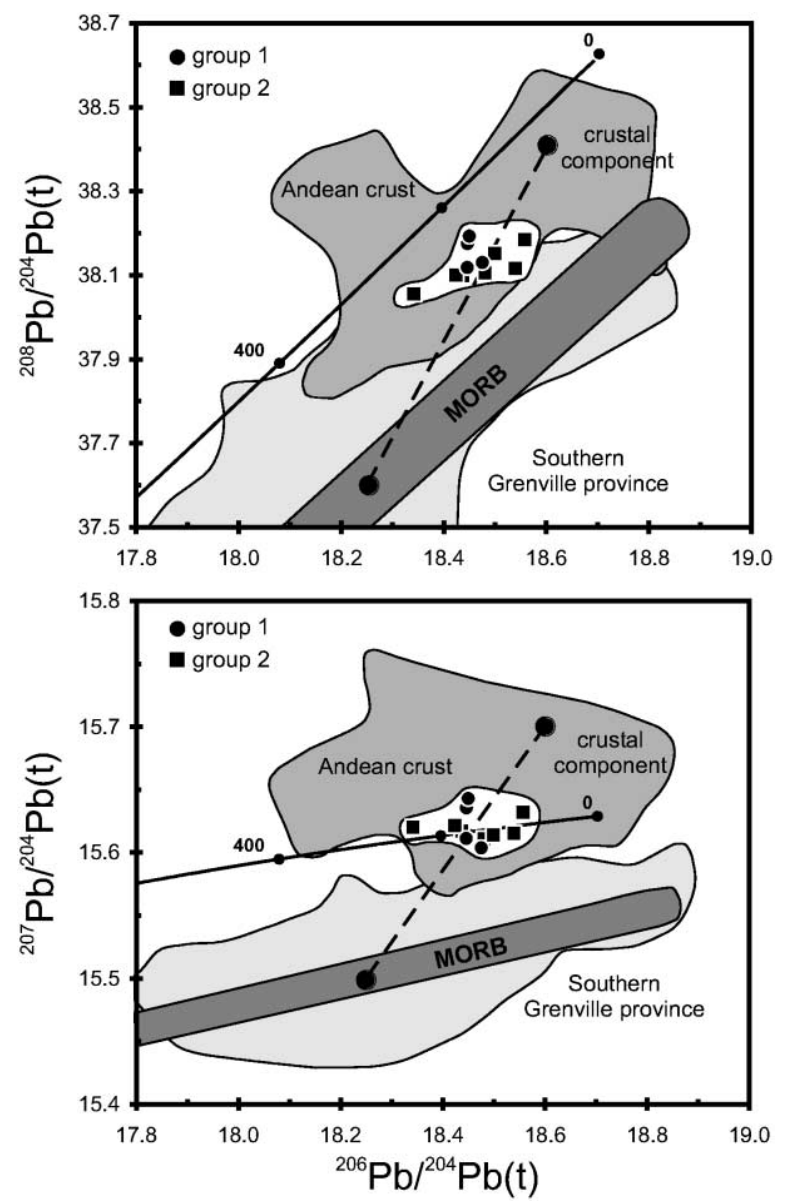

Figure 8. Plot of ${ }^{208} \mathrm{~Pb} /{ }^{204} \mathrm{~Pb}$ and ${ }^{207} \mathrm{~Pb} /{ }^{204} \mathrm{~Pb}$ versus ${ }^{206} \mathrm{~Pb} /$ ${ }^{204} \mathrm{~Pb}$ for the Complejo Igneo Pocitos (CIP) rocks at the time of intrusion. Data fields of mid-ocean ridge basalt (MORB; Hofmann 1997), Andean crust (F. Lucassen, pers. comm.), and Southern Grenville Province (DeWolf and Mezger 1994) are shown for comparison. Data from MORB were back-calculated using a $\mu$ value of 8.5 and a $\omega$ value of 40 . The $\mathrm{Pb}$ isotope composition of the crustal reservoirs were back-calculated applying $\mu$ values of 8 and 10 and $\omega$ values of 30 and 40 . The $\mathrm{Pb}$ isotope composition of all examined CIP samples can be modeled by mixing of average MORB with a crustal component as indicated by schematic mixing lines. The similarity in $\mathrm{Pb}$ isotope composition between the CIP and the Andean crust suggests that the crustal component is dominated by local sources. Incorporation of a component derived from the Southern Grenville Province in North America is not consistent with the $\mathrm{Pb}$ isotope data from the CIP. 

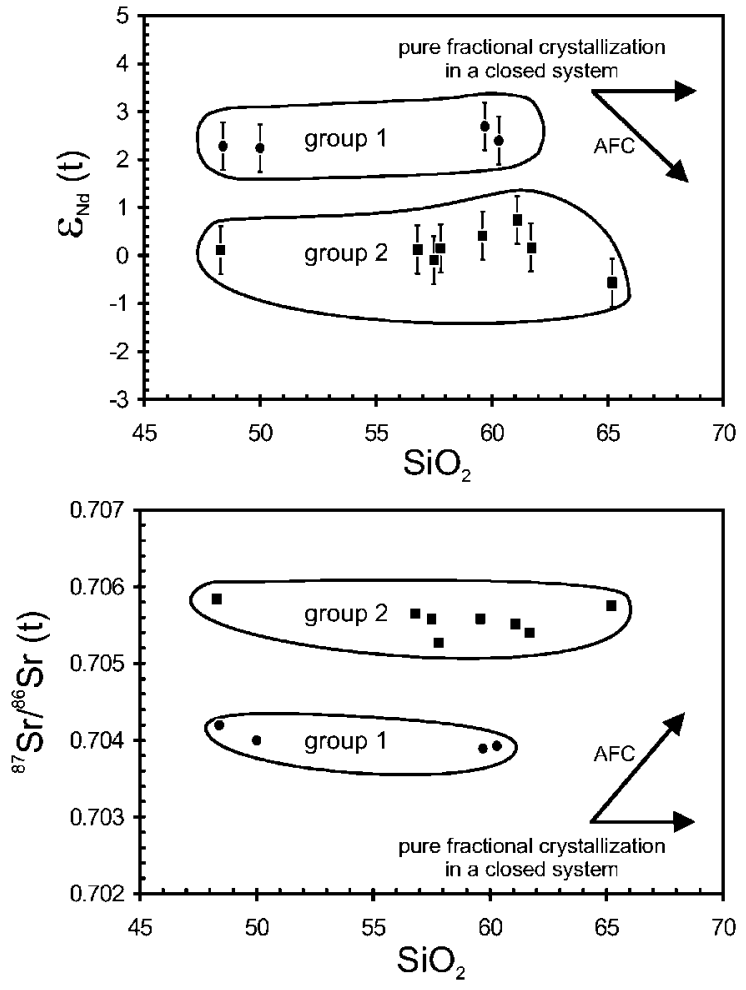

Figure 9. Plots of $\varepsilon_{\mathrm{Nd}}$ and ${ }^{87} \mathrm{Sr} /{ }^{86} \mathrm{Sr}$ versus $\mathrm{SiO}_{2}$. Arrows indicate the schematic magmatic trends for pure fractional crystallization in a closed system and for a combination of assimilation and fractional crystallization (AFC). All examined samples lack evidence of shallowlevel assimilation of continental crust during magma crystallization. The AFC processes therefore appear to be restricted to the deep crustal melting, assimilation, storage, and homogenization zone.

$\mathrm{Nd}-\mathrm{Pb}$ mixing lines between a primitive arc basalt and Andean crust were calculated (fig. 10). The composition of island arc basalts is thought to be unaffected by any significant crustal contamination but reflects in almost all cases incorporation of subducted sediments and MORB-derived fluids in the genesis of the magma (e.g., McCulloch and Gamble 1991). However, the effect of source contamination by subducted sediments on the trace element composition can be considered negligible compared with the compositional variations caused by fluctuations in the input of MORBderived fluids. Therefore, the composition of the average arc basalt reported by McCulloch and Gamble (1991) was chosen here as representative of a primitive arc basalt unaffected by involvement of any crustal material. The isotopic composition of this melt was chosen to be identical to that of the depleted mantle, again neglecting any modification by subducted sediments. The different mixing lines shown in figure 10 refer to assimilation of crustal material of varying compositions, covering the range reported for Andean crust. group 1 samples are too radiogenic in ${ }^{207} \mathrm{~Pb} /{ }^{204}$ and ${ }^{208} \mathrm{~Pb} /{ }^{204} \mathrm{~Pb}$ at a given $\varepsilon_{\mathrm{Nd}}$ to be the result of pure deep crustal MASH processes. The elevated ${ }^{207} \mathrm{~Pb} /{ }^{204} \mathrm{~Pb}$ and ${ }^{208} \mathrm{~Pb} /{ }^{204} \mathrm{~Pb}$ ratios rather indicate significant involvement of subducted sediments, because marine sediments are often characterized by elevated ${ }^{207} \mathrm{~Pb} /{ }^{204} \mathrm{~Pb}$ and ${ }^{208} \mathrm{~Pb} /{ }^{204} \mathrm{~Pb}$ ratios (e.g., Hickey et al. 1986; Ben Othman et al. 1989). The $\mathrm{Nd}$ and $\mathrm{Pb}$ isotope compositions of group 2 rocks, however, are consistent with an origin by deep crustal MASH processes (fig. 10).

Evidence for Source Contamination by MORBDerived Fluids and Subducted Sediments. The combination of $\mathrm{Nd}$ and $\mathrm{Pb}$ isotopes is particularly useful in deciphering mixing processes among the depleted MORB-mantle, MORB-derived fluids, and melts from subducted sediments. Subducted sediments contain orders of magnitude more $\mathrm{Pb}$ than the depleted MORB-mantle and, therefore, control the $\mathrm{Pb}$ isotope composition of subarc mantle domains (e.g., White and Dupré 1986). Mixing between the depleted MORB-mantle and minute amounts of subducted sediments therefore is expected to result in radiogenic $\mathrm{Pb}$ isotope ratios and almost no effect on the $\varepsilon_{\mathrm{Nd}}$ values. Due to the high fluid mobility of $\mathrm{Pb}$ compared to $\mathrm{Nd}$, MORBderived fluids are characterized by high $\mathrm{Pb} / \mathrm{Nd}$ ratios (e.g., Tatsumi et al. 1986). Consequently, addition of MORB-derived fluids as a third component lowers the $\mathrm{Pb}$ isotope composition without changing the $\mathrm{Nd}$ isotope ratio significantly (fig. 11).

$\mathrm{Nd}-\mathrm{Pb}$ mixing lines between the depleted MORBmantle and melts from subducted sediments for different amounts of fluid addition are shown in figure 11 . The similarity in $\mathrm{Pb}$ isotope composition between the CIP and the Andean crust suggests the crustal component in the CIP melts (fig. 8) to be dominated by local sources. The $\mathrm{Nd}$ isotope composition of the subducted sediments, therefore, is assumed to be that of the volcano-sedimentary Formation Tollilar, which gives a good estimate for the upper crustal composition in the area of the southern Puna in Ordovician time (Zimmermann 1999). The $\mathrm{Pb}$ isotope composition of the depleted MORB mantle was deduced from Hofmann (1997), and that of subducted sediments was estimated from the mixing lines shown in figure 8 . The trace element composition of MORB-derived fluids and melts from subducted sediments are from Münker (2000), and the $\mathrm{Nd}$ and $\mathrm{Pb}$ isotope composition of 

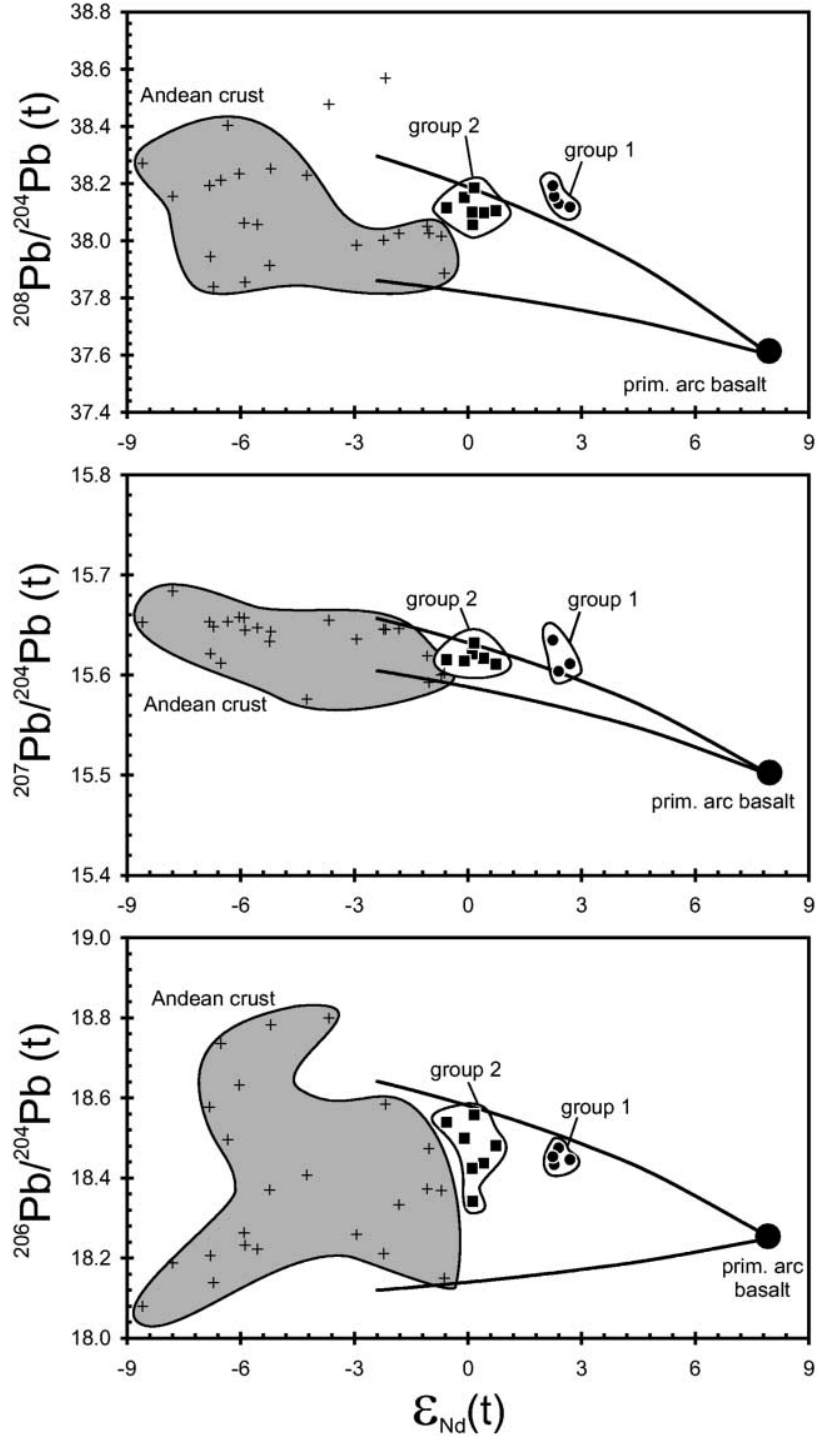

Figure 10. Crustal contamination of a primitive arc basalt in the melting, assimilation, storage, and homogenization (MASH) zone. The $\mathrm{Pb}-\mathrm{Nd}$ assimilation and fractional crystallization (AFC) mixing lines shown were calculated using a value $r$ of 0.6 , which is widely used in modeling deep crustal MASH processes (e.g., Hildreth and Moorbath 1988). The crystallizing mineral assemblage consists of $20 \%$ hornblende, $40 \%$ clinopyroxene, $20 \%$ orthopyroxene, $10 \%$ olivine, and $10 \%$ plagioclase. These phases are generally known to dominate the evolution of basaltic magmas in a volcanic arc setting (e.g., Gill 1981). The partition coefficients used were taken from the following references: plagioclase, orthopyroxene, olivine (Dunn and Sen 1994); clinopyroxene (Hart and Dunn 1993); hornblende (Brenan et al. 1995). The Nd and $\mathrm{Pb}$ concentrations of the endmembers are those of average continental crust (20 and 13 ppm, respectively) and those of the average arc basalt reported by McCulloch and Gamble (1991; 10 and 4 ppm, respectively). The different mixing lines shown refer to assimilation of crustal material of varying isotope compositions. The isotope composition of the Andean crust has been chosen
MORB-derived fluids was chosen to be identical with the values for the depleted mantle. Compositions for the endmembers used are summarized in the caption of figure 11 .

The isotopic composition of group 1 samples can be modeled by admixture of $0.5 \%$ melt from subducted sediment and between $1 \%$ and $2 \%$ MORBderived fluid to the mantle wedge (fig. 11). These results agree very well with those observed for recent arc systems (e.g., White and Patchett 1984; White and Dupré 1986; Ellam and Hawkesworth 1988) and show that the assumptions made in the modeling are valid. The isotope composition of group 2 samples, however, is not in accord with a pure source assimilation model because addition of different amounts of MORB-derived fluid are needed depending on whether the ${ }^{206} \mathrm{~Pb} /{ }^{204} \mathrm{~Pb},{ }^{207} \mathrm{~Pb} /$ ${ }^{204} \mathrm{~Pb}$, or ${ }^{208} \mathrm{~Pb} /{ }^{204} \mathrm{~Pb}$ ratios are used. The $\mathrm{Nd}-\mathrm{Pb}$ isotope composition of group 2 rocks requires an additional component, most likely represented by continental crust, which contaminated the melts during their ascent.

Four Components in Group 2 Magmas: Crustal Contamination in the MASH Zone. As shown in figure 10 , the isotope composition of group 2 samples can be modeled by the modification of primitive arc basalts by AFC processes. In order to better evaluate and quantify the role of crustal assimilation processes in the petrogenesis of group 2 rocks, the effect of combined assimilation and fractional crystallization processes on the $\mathrm{Sr}$ and $\mathrm{Nd}$ isotope composition of the group 1 monzodiorites was modeled. The group 1 monzodiorites provide the best estimate for the composition of the group 2 parental magmas because they have not been modified by crustal contamination during their ascent. The results of the modeling are shown in figure 12. As discussed earlier, crustal contamination is restricted to the deep crustal MASH zone, and therefore a ratio of assimilated to fractionated material $r$ of 0.6 is used in the AFC calculations. All parameters applied in the AFC calculations are summarized in figure 12 .

to be $\varepsilon_{\mathrm{Nd}}=-6,{ }^{208} \mathrm{~Pb} /{ }^{204} \mathrm{~Pb}=37.9-38.4,{ }^{207} \mathrm{~Pb} /{ }^{204} \mathrm{~Pb}=$ $15.58-15.65$, and ${ }^{206} \mathrm{~Pb} /{ }^{204} \mathrm{~Pb}=18.1-18.55$. Using a less negative $\varepsilon_{\mathrm{Nd}}$ value steepens the AFC mixing lines but would result in an unreasonable high assimilation rate of around $80 \%$ or even higher values. The crustal contamination model only can account for the isotope composition of group 2 samples but not for the isotope composition of group 1 rocks. 

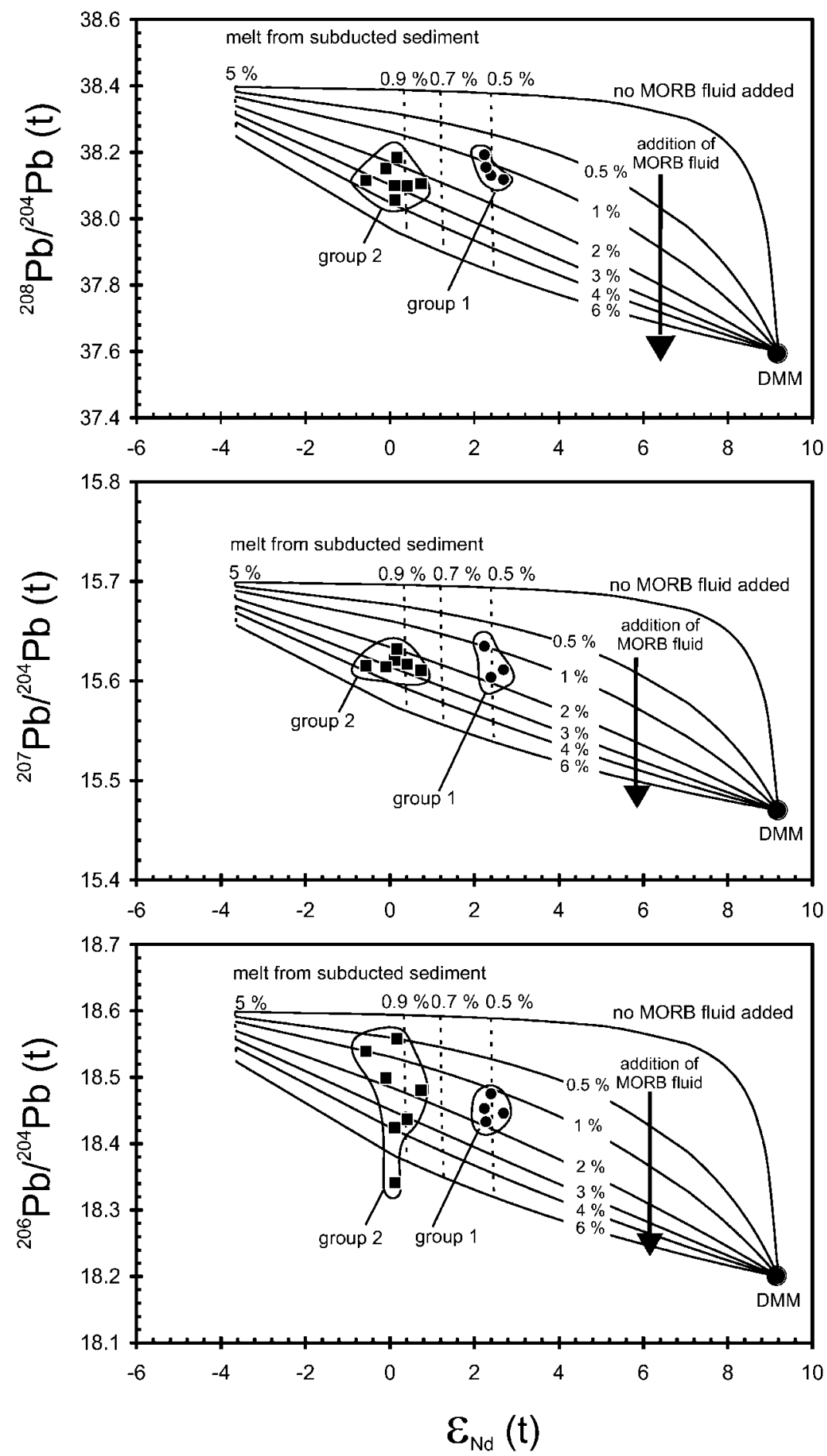

Figure 11. Modeling source contamination by subducted sediments and mid-ocean-ridge-basalt-derived (MORBderived) fluids. The solid lines are calculated three-component $\mathrm{Pb}-\mathrm{Nd}$ isotope-mixing curves among the depleted mantle wedge $(\mathrm{DMM} \mathrm{Nd}=0.7 \mathrm{ppm}, \mathrm{Pb}=0.018 \mathrm{ppm})$, a $15 \%$ melt from subducted sediment $(\mathrm{Nd}=135 \mathrm{ppm}$, $\mathrm{Pb}=129 \mathrm{ppm})$, and a fluid derived from the MORB portion of the downgoing slab ( $\mathrm{Nd}=1 \mathrm{ppm}, \mathrm{Pb}=25 \mathrm{ppm})$. The trace element composition of both melt from subducted sediments and MORB-derived fluid are from Münker (2000). $\mathrm{Nd}$ and $\mathrm{Pb}$ concentrations for the DMM are from Geochemical Earth Reference Model, and the Nd isotope composition is deduced from MORB data from Hofmann (1997). The Pb isotope composition of the DMM and the subducted sediments were estimated from the mixing lines shown in figure 8 . The $\mathrm{Nd}$ isotope composition of subducted sediments was assumed to be that of the volcano sedimentary formation Tollilar (Zimmermann 1999). The isotope composition of MORB-derived fluids is identical to that of the DMM. The Pb isotope composition of the threecomponent mixture is strongly controlled by the input of subducted sediments. However, addition of MORB- 
The parental melt of group 2 samples can be produced by crustal contamination of a melt sampled by the group 1 monzodiorites and concomitant crystallization of $30 \%-40 \%$ of the magma body in the deep crustal MASH zone. Using an $r$ value of 0.6 , this refers to assimilation of $20 \%-25 \%$ of crustal material (fig. 12). As indicated by variations in the $\mathrm{Zr}$ content of both CIP parental magmas, further intrasuite fractionation of the melts in a closed system following contamination in the deep crustal MASH zone is required (fig. 12). This differentiation process took place after efficient homogenization of the contaminated magma and was not accompanied by crustal assimilation, thus maintaining the isotope composition of the melts constant. This process most likely occurred at shallower crustal levels where only insufficient heat was generated during fractional crystallization of the magma to assimilate crustal material. During these intrasuite differentiation processes, the more evolved melts from both groups and the group 2 monzodiorite (sample T 18) were generated. The group 2 monzodiorite cannot represent the parental magma of group 2, because its low $\mathrm{SiO}_{2}$ content of $48 \mathrm{wt} \%$ can barely be explained by crustal contamination. Assuming a $\mathrm{SiO}_{2}$ content of $60 \mathrm{wt} \%$ for the contaminating crust, the lower limit of the $\mathrm{SiO}_{2}$ content of the group 2 parental magma can be estimated by simple mass balance to $\sim 52 \mathrm{wt} \%$. The true $\mathrm{SiO}_{2}$ content for the contaminated melt is probably higher, because further $\mathrm{SiO}_{2}$ enrichment results from fractional crystallization accompanying the process of crustal contamination. Due to its low $\mathrm{SiO}_{2}$ content, the group 2 monzodiorite can be interpreted as a cumulate mainly consisting of hornblende.

In deep crustal MASH processes, garnet might be expected to occur as a residual phase (McMillan et al. 1993). In this case, the REE in the CIP melts should be strongly fractionated, because garnet preferentially incorporates the heavy REE in its crystal lattice. The REE abundances of the CIP samples, however, are significantly less fractionated than would be expected from the presence of residual garnet. Melting experiments in tonalitic systems have shown that garnet only occurs as a residual phase at relatively low degrees of partial melting (Caroll and Wyllie 1989; Skjerlie and John- ston 1992), suggesting that garnet in the source of the CIP melts was consumed during earlier magmatism, if it was present at all.

All geochemical data combined are consistent with the following petrogenetic model: all CIP magmas are derived from a typical subarc mantle source previously enriched by addition of $\sim 0.5 \%$ sediment melt and $1 \%-2 \%$ MORB-derived fluids. The overall similarity in major and trace element compositions among all examined samples can be attributed to an origin by subduction-related magmatic processes. The development of two parental magmas, each with a distinct and homogeneous isotope composition, can be attributed to the different extent of crustal assimilation processes, which were only important during the petrogenesis of group 2 samples. The constant $\mathrm{Sr}$ and $\mathrm{Nd}$ isotope composition at varying $\mathrm{SiO}_{2}$ restricts the crustal contamination to the deep crustal MASH zone, resulting in an efficient homogenization of the magmas. Assimilation of crustal material provided an additional source of incompatible trace elements and therefore can account for the higher degree of enrichment of most of the incompatible trace elements at a given $\mathrm{SiO}_{2}$ content observed for group 2 samples.

\section{Conclusions and Geodynamic Implications}

The CIP magmas were generated in an Ordovician continental arc. The identification of deep crustal MASH processes requires that this arc was built on thickened continental crust in order to enable melting and assimilation processes at the base of the crust (e.g., Hildreth and Moorbath 1988). The Nd$\mathrm{Pb}$ isotope composition of the CIP indicates a Middle Proterozoic age for the continental crust in the study area. Similarly, Pankhurst et al. (1998) proposed that the underlying crust of the Ordovician Famatinian arc in the Southern Andes is of Middle Proterozoic age. The CIP, therefore, can be considered to be the northern continuation of the Famatinian arc, which extended from central Argentina to northern Chile. Given the rather homogeneous Middle Proterozoic Nd model ages of the Late Precambrian-Early Paleozoic metamorphic basement in the area between the Arequipa Massif in the North and the Argentine Precordillera

derived fluid to a mixture of $\mathrm{DMM}$ and subducted sediment lowers the $\mathrm{Pb}$ isotope signature significantly without affecting the $\mathrm{Nd}$ isotope composition. The source contamination model can account for the isotope composition of group 1 rocks but not for the isotope composition of group 2 samples. 

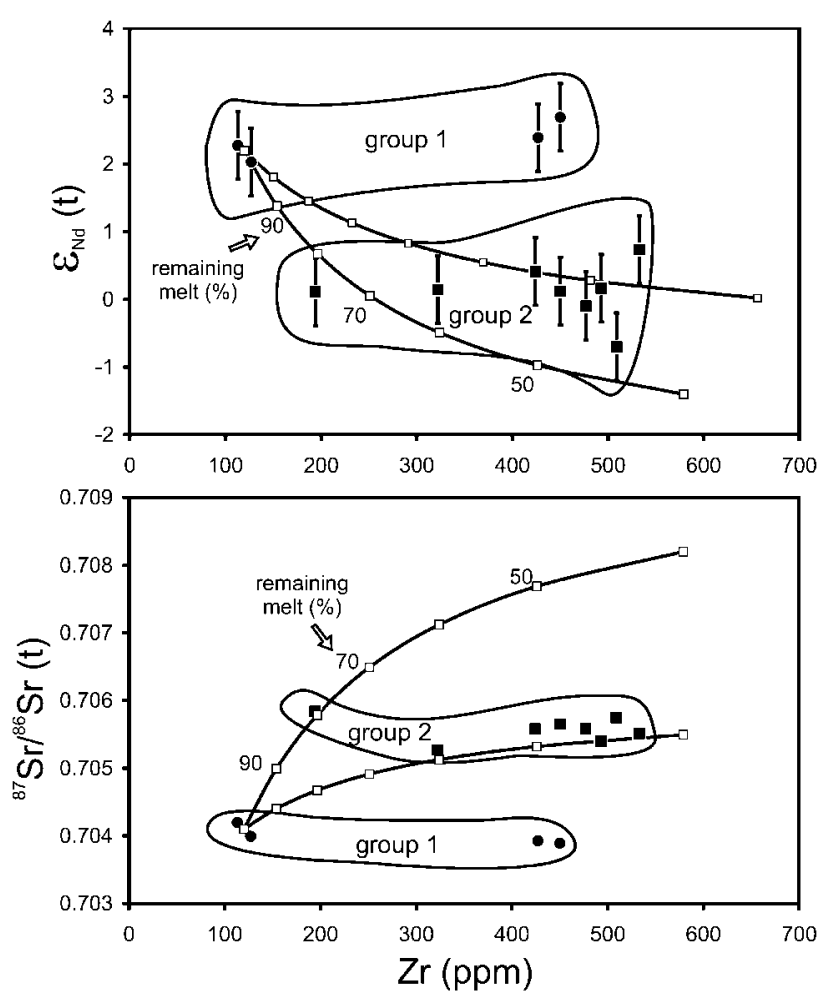

Figure 12. Plots of $\varepsilon_{\mathrm{Nd}}$ and ${ }^{87} \mathrm{Sr} /{ }^{86} \mathrm{Sr}$ versus $\mathrm{Zr}$ with assimilation and fractional crystallization (AFC) mixing lines between group 1 monzodiorites and Andean continental crust. For the ratio of assimilated to fractionated material as well as the composition of the crystallizing mineral assemblage, see figure 10 . The different mixing lines shown refer to assimilation of crustal material of varying isotope composition. The $\mathrm{Sr}$ and $\mathrm{Nd}$ isotope composition of the contaminant was estimated from the data field in figure 7 and ranges from ${ }^{87} \mathrm{Sr} /{ }^{86} \mathrm{Sr}=0.709$ to 0.719 and $\varepsilon_{\mathrm{Nd}}$ values between -9 and -3 . The $\mathrm{Sr}, \mathrm{Nd}$, and $\mathrm{Zr}$ concentrations of Andean continental crust are the values for average continental crust $(330,20$, and 120 ppm, respectively). Assimilation of $20 \%-25 \%$ crustal material and concomitant crystallization of $30 \%-40 \%$ of the magma body results in a melt isotopically indistinguishable from the group 2 parental magma.

in the South (Lucassen et al. 2000) and of Paleozoic sedimentary rocks from northern Chile and northwestern Argentina (Bock et al. 2000), extension of the Ordovician Famatinian arc further north up to the Arequipa Massif seems possible. Thickening of the crust on which the Famatinian arc was built can be related to the Pampean orogeny at $\sim 500 \mathrm{Ma}$ (Lucassen et al. 2000).

The Puna ultramafic rocks are of Proterozoic age and part of the crustal block on which the Ordovician arc was built. These results render it un- likely that the Puna ultramafics represent ophioithes related to a Paleozoic terrane boundary (e.g., Bahlburg et al. 1997). This interpretation is consistent with $\mathrm{Nd}$ isotope evidence from Paleozoic sedimentary rocks from this region that preclude any significant obduction of ocean floor (Bock et al. 2000). The Early Ordovician intrusive rocks of the Archibarca granite in the western reaches of the southern Puna have the same age as the CIP and have been interpreted as witnesses of an Early Paleozoic subduction zone (Palma et al. 1986; Bahlburg and Hervé 1997). At a given $\mathrm{SiO}_{2}$ content, rocks from the Archibarca granite display lower alkali metal concentrations than the CIP samples (data in Coira et al. 1999), which is consistent with the assumption of an east-dipping subduction zone at the proto-Andean margin of Gondwana (e.g., Rapela et al. 1998).

A comparison of the Ordovician Famatinian arc with the recent continental arc of the Andes provides important constraints on the structure of the Ordovician arc. The rate of crustal assimilation observed for magmas from the volcanic zone of the Andes almost always seems to reach values around $20 \%$ (G. Wörner, pers. comm.). A similar assimilation rate of $20 \%-25 \%$ has been deduced for the CIP magmas, indicating a strong similarity between the MASH processes active in the Ordovician and Andean continental arcs. In the Andes, variations in the chemical and isotopic composition of volcanic rocks can be related to changes in the composition and thickness of the continental crust (e.g., Hickey et al. 1986; Hildreth and Moorbath 1988; Davidson et al. 1990; McMillan et al. 1993). Andean volcanic rocks exhibit a more crustlike Sr-Nd isotope composition than the CIP, indicating that thicknesses of the Ordovician crust in the area of the CIP were lower than in the present Andes. Likewise, volcanic rocks from central Argentina sampling the southern part of the Famatinian arc display a more crustlike $\mathrm{Sr}-\mathrm{Nd}$ isotope composition than the CIP, suggesting that the thickness of the continental crust onto which the Famatinian arc was built decreased from south to north.

\section{A C K N O W L E D G M E N T S}

We thank F. Lucassen and B. Bock for providing unpublished data. H. Baier and S. Rochnowski are thanked for technical assistance. M. Bröcker, M. Rehkämper, and E. Scherer are thanked for helpful discussions. 


\section{R E F E R E N C E S C I T E D}

Arculus, R. J., and Powell, R. 1986. Source component mixing in the regions of arc magma generation. J. Geophys. Res. 91:5913-5926.

Bahlburg, H. 1998. The geochemistry and provenance of Ordovician turbidites in the Argentinian Puna. In Pankhurst, R. J., and Rapela, C. W., eds. The protoAndean Margin of Gondwana. Geol. Soc. Spec. Pap. 142:127-142.

Bahlburg, H., and Hervé, F. 1997. Geodynamic evolution and tectonostratigraphic terranes of northwestern Argentina and northern Chile. Geol. Soc. Am. Bull. 109: 869-884.

Bahlburg, H.; Kay, S. M.; and Zimmermann, U. 1997. New geochemical and sedimentological data on the evolution of the Early Paleozoic Gondwana margin in the southern central Andes. Geol. Soc. Am. Meeting Abstr. Vol., p. A-378.

Bahlburg, H.; Moya, M. C.; Zimmermann, U.; Bock, B.; and Hervé, F. 2000. Paleozoic plate tectonic evolution of the western Gondwana margin in northern Chile and northwestern Argentina. Z. Angew. Geol. SH1: 345-353.

Barton, M. D.; Ilchik, R. P.; and Marikos, M. A. 1991. Metasomatism. In Kerrick, D. M., ed. Contact metamorphism. Rev. Mineral. 26:321-350.

Ben Othman, D.; White, W. M.; and Patchett, J. 1989. The geochemistry of marine sediments, island arc magma genesis, and crust-mantle recycling. Earth Planet. Sci. Lett. 94:1-21.

Blasco, G.; Villar, L.; and Zappettini, E. O. 1996. El complejo ofiolítico desmambrado de la Puna Argentina, Províncias de Jujuy, Salta y Catamarca. XIII Congreso Geológico Argentino y III Congreso de Exploracón de Hidrocarburos, Acta III:653-667.

Bock, B.; Bahlburg, H.; Wörner, G.; and Zimmermann, U. 2000. Tracing crustal evolution in the southern central Andes from Late Precambrian to Permian using $\mathrm{Nd}$ and $\mathrm{Pb}$ isotopes. J. Geol. 108:515-535.

Brenan, J. M.; Shaw, H. F.; Ryerson, F. J.; and Phinney, D. L. 1995. Experimental determination of trace element partitioning between pargasite and a synthetic hydrous andesitic melt. Earth Planet. Sci. Lett. 135:111 .

Cameron, A. E.; Smith, D. H.; and Walker, R. L. 1967. Mass spectrometry of nanogram-size samples of lead. Anal. Chem. 41:525-526.

Caroll, M. R., and Wyllie, P. J. 1989. Experimental phase relations in the system tonalite-peridotite- $\mathrm{H}_{2} \mathrm{O}$ at 15 $\mathrm{kb}$ : implications for assimilation and differentiation processes near the crust-mantle boundary. J. Petrol. 30:1351-1382.

Coira, B.; Kay, S. M.; Peréz, B.; Woll, B.; Hanning, M.; and Flores, P. 1999. Magmatic sources and tectonic setting of Gondwana margin Ordovician magmas, northern Puna of Argentina and Chile. In Ramos, V. A., and Keppie, J. D., eds. Laurentia-Gondwana con- nections before Pangaea. Geol. Soc. Am. Spec. Publ. 336:147-169.

Dalla Salda, L. H.; Cingolani, C. A.; and Varela, R. 1992. Early Paleozoic orogenic belt of the Andes of southwestern South America: result of LaurentiaGondwana collision? Geology 20:616-620.

Dalziel, I. W. D. 1997. Neoproterozoic-Paleozoic geography and tectonics: review, hypothesis, environmental speculation. Geol. Soc. Am. Bull. 109:16-42.

Dalziel, I. W. D.; Dalla Salda, L. H.; and Gahagan, L. M. 1994. Paleozoic Laurentia-Gondwana interaction and the origin of the Appalachian-Andean mountain system. Geol. Soc. Am. Bull. 106:243-252.

Damm, K.-W.; Harmon, R. S.; and Kelley, S. 1994. Some isotopic and geochemical constraints on the origin and evolution of the central Andean Basement (19 $\left.-24^{\circ} \mathrm{S}\right)$. In Reutter, K. J.; Scheuber, E.; and Wigger, S., eds. Tectonics of the southern central Andes: structure and evolution of an active continental margin. Heidelberg, Springer.

Damm, K.-W.; Pichowiak, S.; Harmon, R. S.; Todt, W.; Omarini, R.; and Niemeyer, H. 1990. Pre-Mesozoic evolution of the central Andes: the basement revisited. Geol. Soc. Am. Spec. Pap. 241:101-126.

Davidson, J. P.; McMillan, N. J.; Moorbath, S.; Wörner, G.; Harmon, R. S.; and Lopez-Escobar, L. 1990. The Nevados de Payachata volcanic region $\left(18^{\circ} \mathrm{S} / 69^{\circ} \mathrm{W}, \mathrm{N}\right.$. Chile). II. Evidence for widespread crustal involvement in Andean magmatism. Contrib. Mineral. Petrol. 105:412-432.

DePaolo, D. J. 1981. Trace element and isotopic effects of combined wallrock assimilation and fractional crystallisation. Earth Planet. Sci. Lett. 53:189-202.

DeWolf, C. P., and Mezger, K. 1994. Lead isotope analyses of leached feldspars: constraints on the early crustal history of the Grenville Orogen. Geochim. Cosmochim. Acta 58:5537-5550.

Dunn, T., and Sen, C. 1994. Mineral/matrix partition coefficients for orthopyroxen, plagioclase, and olivine in basaltic to andesitic systems: a combined analytical and experimental study. Geochim. Cosmochim. Acta 58:717-733.

Ellam, R. M., and Hawkesworth, C. J. 1988. Elemental and isotopic variations in subduction related basalts: evidence for a three component model. Contrib. Mineral. Petrol. 98:72-80.

Gill, J. B. 1981. Orogenic andesites and plate tectonics. Berlin, Springer.

Goldstein, S. L.; O'Nions, R. K.; and Hamilton, P. J. 1984. A Sm-Nd isotopic study of atmospheric dust and particulates from major river systems. Earth Planet. Sci. Lett. 70:221-236.

Hart, S. R., and Dunn, T. 1993. Experimental cpx/melt partitioning of 24 trace elements. Contrib. Mineral. Petrol. 113:1-8.

Hickey, R. L.; Frey, F. A.; and Gerlach, D. C. 1986. Mul- 
tiple sources for basaltic rocks from the southern volcanic zone of the Andes $\left(34^{\circ}-41^{\circ} \mathrm{S}\right)$ : trace element and isotopic evidence for contributions from subducted oceanic crust, mantle, and continental crust. J. Geophys. Res. 91:5963-5983.

Hildreth, W., and Moorbath, S. 1988. Crustal contributions to arc magmatism in the Andes of central Chile. Contrib. Mineral. Petrol. 98:455-489.

Hofmann, A. W. 1988. Chemical differentiation of the earth: the relationship between mantle, continental crust and oceanic crust. Earth Planet. Sci. Lett. 90: 297-314.

- 1997. Mantle geochemistry: the message from oceanic volcanism. Nature 385:219-229.

Johnson, M. C., and Plank, T. 1999. Dehydration and melting experiments constrain the fate of subducted sediments. Geochem. Geophy. Geosyst. 1:1999GC 000014.

Lucassen, F.; Becchio, R.; Wilke, H. G.; Franz, G.; Thirlwall, M. F.; Viramonte, J.; and Wemmer, K. 2000. Proterozoic-Paleozoic development of the basement of the central Andes (18-26 S): a mobile belt of the South American craton. J. S. Am. Earth Sci. 13:697-715.

Ludwig, K. R. 1991. ISOPLOT: a plotting and regression program for radiogenic-isotope data. Version 2.53. U.S. Geol. Surv. Open File Rep. 91-0445.

Ludwig, K. R., and Silver, L. T. 1977. Lead-isotope inhomogeneity in Precambrian igneous K-feldspars. Geochim. Cosmochim. Acta 41:1457-1471.

McCulloch, M. T., and Gamble, J. A. 1991. Geochemical and geodynamical constraints on subduction zone magmatism. Earth Planet. Sci. Lett. 102:358-374.

McMillan, N. J.; Davidson, J. P.; Wörner, G.; Harmon, R. S.; Moorbath, S.; and Lopez-Escobar, L. 1993. Influence of crustal thickening on arc magmatism: Nevados de Payachata volcanic region, northern Chile. Geology 21:467-470.

Miller, C. F., and Mittlefehlt, D. W. 1982. Depletion of light rare earth elements in felsic magmas. Geology 10:129-133.

Mon, R., and Hongn, F. 1991. The structure of the Precambrian and lower Paleozoic basement of the central Andes between $22^{\circ}-32^{\circ} \mathrm{S}$ Lat. Geol. Rundsch. 80:745758.

Münker, C. 2000. The isotope and trace element budget of the Cambrian Devil River arc system, New Zealand: identification of four source components. J. Petrol. 41:759-788.

Palma, M. A.; Parica; P. D.; and Ramos, V. A. 1986. El granito Archibarca: su edad y significado tectonico, Provincia de Catarmarca. Assoc. Geol. Arg. Rev. 41: 414-419.

Pankhurst, R. J., and Rapela, C. W. 1998. The protoAndean margin of Gondwana: an introduction. In Pankhurst, R. J., and Rapela, C. W., eds. The protoAndean margin of Gondwana. Geol. Soc. Spec. Pap. 142:1-10.

Pankhurst, R. J.; Rapela, C. W.; Saavedra, J.; Baldo, E.; Dahlquist, J.; Pascua, I.; and Fanning, C. M. 1998. The Famatinian magmatic arc in the central Sierras Pam- peanas: an Early to Mid-Ordovician continental arc on the Gondwana margin. In Pankhurst, R. J., and Rapela, C. W., eds. The proto-Andean margin of Gondwana. Geol. Soc. Spec. Pap. 142:343-367.

Pearce, J. W., and Peate, D. W. 1995. Tectonic implications of the composition of volcanic arc magmas. Annu. Rev. Earth Planet. Sci. 23:1331-1358.

Ramos, V. A. 1988. Late Proterozoic-Early Paleozoic of South America: a collisional history. Episodes 11:168174.

Ramos, V. A.; Jordan, T. E.; Allmendinger, R. W.; Mpodozis, C.; Kay, S. M.; Cortes, J. E.; and Palma, M. 1986. Paleozoic terranes of the central Argentine-Chilean Andes. Tectonics 5:855-880.

Rapela, C. W.; Pankhurst, R. J.; Casquet, C.; Baldo, E.; Saavedra, J.; and Galindo, C. 1998. Early evolution of the proto-Andean margin of South America. Geology 26:707-710.

Sisson, T. W., and Grove, T. L. 1993a. Experimental investigations of the role of $\mathrm{H}_{2} \mathrm{O}$ in calc-alkaline differentiation and subduction zone magmatism. Contrib. Mineral. Petrol. 113:143-166.

- $1993 b$. Temperatures and $\mathrm{H}_{2} \mathrm{O}$ contents of low$\mathrm{MgO}$ high-alumina basalts. Contrib. Mineral. Petrol. 113:166-184.

Skjerlie, K. P., and Johnston, A. D. 1992. Vapor-absent melting at $10 \mathrm{kbar}$ of a biotite- and amphibole-bearing tonalitic gneiss: implications for the generation of Atype granites. Geology 20:263-266.

Stacey, J. S., and Kramers, J. D. 1975. Approximation of terrestrial lead isotope evolution by a two stage model. Earth Planet. Sci. Lett. 26:207-221.

Tatsumi, Y.; Hamilton, D. L.; and Nesbitt, R. W. 1986. Chemical characteristics of fluid phase released from a subducted lithosphere and origin of arc magmas: evidence from high-pressure experiments and natural rocks. J. Volcanol. Geotherm. Res. 29:293-309.

White, W. M., and Dupré, B. 1986. Sediment subduction and magma genesis in the Lesser Antilles: isotopic and trace element constraints. J. Geophys. Res. 91:59275941.

White, W. M., and Patchett, P. J. 1984. Hf-Nd-Sr isotopes and incompatible element abundances in island arcs: implications for magma origin and crust mantle evolution. Earth Planet. Sci. Lett. 67:167-185.

Zappettini, E. O.; Blasco, G.; and Villar, L. M. 1994. Geología del extremo sur del Salar de Pocitos, Província de Salta, República Argentina. VII Congreso Geologíco Chileno, Actas I:220-224.

Zimmermann, U. 1999. Sedimentpetrographische, geochemische und isotopengeochemische Methoden zur Bestimmung der Beziehung von Provenienz und Ablagerungsraum an aktiven Kontinentalrändern: das ordovizische Back-Arc-Becken in der Süd-Puna, Hochland im Nordwesten Argentiniens. Dissertation, Universität Heidelberg, Heidelberg.

Zimmermann, U., and Bahlburg, H. 2004. Provenance analysis and tectonic setting of the Ordovician deposits in the southern Puna basin, NW Argentina. Sedimentology 51:1079-1104. 